\title{
Are trees buffering ecosystems and livelihoods in agricultural landscapes of the Lower Mekong Basin? Consequences for climate-change adaptation
}

Minh Ha Hoang, Meine van Noordwijk, Jefferson Fox, David Thomas, Fergus Sinclair, Delia Catacutan, Ingrid Öborn, Tony Simons 



\section{Are trees buffering ecosystems and livelihoods in agricultural landscapes of the Lower Mekong Basin? Consequences for climate-change adaptation}

Minh Ha Hoang, Meine van Noordwijk, Jefferson Fox, David Thomas, Fergus Sinclair, Delia Catacutan, Ingrid Öborn, Tony Simons 


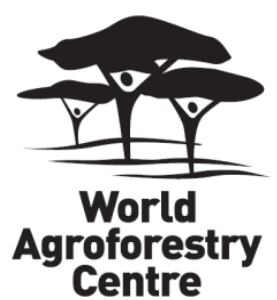

\section{Correct citation}

Hoang MH, van Noordwijk M, Fox J, Thomas D, Sinclair F, Catacutan D, Öborn I, Simons T. 2014. Are trees buffering ecosystems and livelihoods in agricultural landscapes of the Lower Mekong Basin? Consequences for climate-change adaptation. Working Paper 177. Bogor, Indonesia: World Agroforestry Centre (ICRAF) Southeast Asia Regional Program. DOI: 10.5716/WP14047.PDF

Titles in the Working Paper series share interim results on agroforestry research and practices to stimulate feedback from the scientific community. Other publication series from the World Agroforestry Centre include agroforestry perspectives, technical manuals and occasional papers.

Published by the World Agroforestry Centre (ICRAF)

Southeast Asia Regional Program

Jalan CIFOR, Situ Gede, Sindang Barang

Bogor Barat 16115, Jawa Barat

Indonesia

Website: http://worldagroforestry.org/regions/southeast_asia

(C) World Agroforestry Centre 2014

\section{Correspondence}

Minh Ha Hoang

World Agroforestry Centre (ICRAF) Viet Nam office

No.8, Lot 13A, Trung Hoa Street, Yen Hoa Ward

Cau Giay District, Hanoi, Viet Nam

Phone and fax: $+84437834644 / 45$

Email: m.h.hoang@cgiar.org

\section{Disclaimer and copyright}

The views expressed in this publication are those of the authors and not necessarily those of the World Agroforestry Centre. This publication may be quoted or reproduced without charge, provided the source is acknowledged. All images remain the sole property of their source and may not be used for any purpose without written permission of the source. 


\section{About the authors}

\section{Minh Ha Hoang}

is a senior scientist and ICRAF fellow. She has 18 years of working experience in Southeast Asia, Kenya and Sweden as a consultant and scientist. Her speciality is in the fields of agroforestry and land-use and natural resources management with an emphasis on soil-plant-crop-human interactions at field and landscape levels. Minh Ha holds a PhD in agronomy and soil science from the Swedish University of Agricultural Sciences in Uppsala and post-doctoral training in sustainable land uses at the landscape level conducted through the World Agroforestry Centre Southeast Asia program.

\section{Meine van Noordwijk}

In addition to being Chief Science Advisor for the Centre, Meine van Noordwijk leads the organization-wide environmental services research area. From 2002 to 2008 he was regional coordinator for Southeast Asia. Before joining the Centre, Meine was a senior research officer in the Root Ecology Section at the DLO Institute for Soil Fertility Research in Haren, the Netherlands, concentrating on models of the relationships between soil fertility, nutrient-use efficiency and the root development of crops and trees. He also worked for two years as a lecturer in botany and ecology at the University of Juba in Sudan. Meine has a PhD in agricultural science from the University of Wageningen, the Netherlands, and an MSc in Biology from the Rijksuniversiteit Utrecht, the Netherlands.

\section{Jefferson Fox}

is a senior fellow at the East-West Center in Honolulu. He studies land-use and land-cover changes in Asia and the possible cumulative impact of these on the regional and global environments. His research includes 'Coupled natural-human systems and emerging infectious diseases: anthropogenic environmental change and avian influenza in Vietnam', funded by the US National Science Foundation, and 'Forest, agricultural, and urban transitions in mainland Southeast Asia: synthesizing knowledge and developing theory', funded by the National Aeronautics and Space Agency. He has worked in Bangladesh, Cambodia, China, Indonesia, Laos, Myanmar, Nepal, Thailand and Viet Nam.

\section{David Thomas}

is a consultant and former senior policy analyst with the World Agroforestry Centre. He was based in Thailand for more than 30 years, working with organizations focused on natural resource management and rural development in mainland Southeast Asia.

\section{Fergus Sinclair}

As the leader of ICRAF's Agroforestry Systems science domain, Fergus leads the Centre's research into the contribution that trees can make to the productivity of farming systems and rural people's lives. This domain has two main areas of focus: soil and water productivity; and factors affecting farmers' decisions about which trees they incorporate on their farms and how they manage them. $\mathrm{He}$ also co-ordinates the Smallholder Production Systems and Markets component of the CGIAR Research Program on Forests, Trees and Agroforestry, which involves the Center for International Forestry Research, Bioversity and the Centro Internacional de Agricultura Tropical and is ICRAF's focal point for integrated agricultural research in the humid tropics and dryland systems. Fergus is known for pioneering development of knowledge-based systems' methods for acquisition and use of local agro-ecological knowledge, for using participatory modelling to better harness natural resources at community level and for exploring trade-offs between the impact of farm trees on productivity and biodiversity.

\section{Tony Simons}

is the director general of the World Agroforestry Centre. Tony has worked for 27 years on issues at the tropical agriculture/forestry interface in more than 40 developing countries. His work has spanned the private sector (Shell Forestry), academe (University of Oxford), official development assistance (ODA/DFID) and research (CGIAR). He holds a bachelor's degree in agricultural science from Massey University, New Zealand, as well as master's and doctoral degrees from Cambridge 
University, UK. In 2009, he was made an honorary professor in tropical forestry at the University of Copenhagen. Tony is a member of the boards of the Africa Centre of Technology Studies, Plant Resources of Tropical Africa, Danone Livelihoods Fund and DCM International Imaging. He is also the leader of the International Union of Forestry Research Organizations' Forest and Water Task Force. He has published over 100 research papers and has sat on several journals' editorial boards. His interests span the seven major research themes of ICRAF.

\section{Delia Catacutan}

is senior social scientist and country representative of ICRAF in Viet Nam. She conducts research on integrated natural resources management, focusing on institutions and policies for enhanced delivery of ecosystem services, landscape management, tenure and property rights, and gender. Delia has a doctorate in natural and rural systems management and post-doctoral training in sustainability science.

\section{Ingrid Öborn}

is a senior research fellow with ICRAF in Nairobi, Kenya. She has a PhD in soil science and holds a faculty chair in agricultural cropping systems at the Swedish University of Agricultural Sciences in Uppsala, Sweden. Ingrid is also a visiting professor in crop production ecology at Scotland's Rural College in Edinburgh, UK. 


\section{Abstract}

People and ecosystems in the Lower Mekong Basin (LMB) are vulnerable owing to the interaction between unsustainable land-use practices and climate change. This review analyzes 1)) the impacts of continuing land-use and climate changes in the LMB region; and 2) the potential role of increased use of trees in agricultural landscapes to reduce the negative impact of land-use changes. The analysis was based on a review of peer-reviewed literature identified by a keyword search and related unpublished data of the World Agroforestry Centre Thailand. The study confirms that natural resources and ecosystem servicesparticularly water, soil and biodiversity - are degrading in the LMB. However, trees outside forests, including agroforests, can help buffer both ecosystems and local livelihoods in agricultural landscapes, thereby enhancing their resilience. Several remaining challenges are discussed according to their links to technical, policy and social capital-building issues. Combining local knowledge and scientific knowledge in selecting optimal combinations and spatial arrangements of suitable trees and agroforestry practices is necessary in order to maximize synergies and reduce trade-offs among different ecosystem services, between ecosystem benefits and economic benefits, and between climate-change adaptation and mitigation purposes. Policy recommendations centre on strategies for participatory approaches, on enhancing agroforestry advocacy and on co-interest incentive schemes at farm scale to help address sustainability of agricultural landscapes. Further research is recommended on suitable trees and agroforestry practices to address identified transboundary issues, using a holistic landscape approach with high levels of participation and a nested framework for ecosystem management and monitoring.

Keywords: agroforestry, climate change, multifunctionality, tree-based strategy, vulnerability, 'climate-smart' landscape, buffering, resilience, ecosystems 


\section{Acknowledgements}

This research was funded by the World Agroforestry Centre under two CGIAR research programs: 1) Forests, Trees and Agroforests' component 6.3: Landscape management for environmental services, biodiversity conservation and livelihoods; and 2) Agriculture for Nutrition and Health's component 1.2: Integrated systems for the humid tropics. Analyses of land use in the Mae Chaem catchment were conducted by ICRAF Thailand based on remote sensing data from the Royal Forest Department and from a project led by the East-West Center and funded by the US National Science Foundation; remote sensing analysis and GIS processing were conducted by Anantika Ratnamhin.

The authors are grateful for the internal review and inputs of Dr Sara Scherr (Ecoagriculture), Dr Peter Minang, Prof Dr Jianchu Xu, Dr Sonya Dewi, Dr Beria Leimona, Dr Grace Villamor, Dr Eike Luedeling and Mr Scott Bode (ICRAF) and Dr Anders Malmers (SLU). Mr Robert Finlayson edited the text. 


\section{Content}

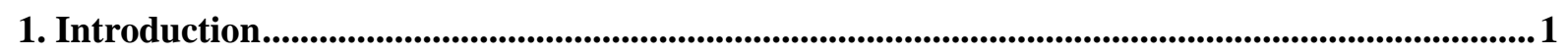

2. Theory and methods ....................................................................................................................................3

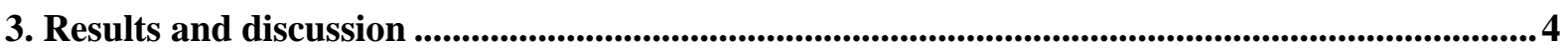

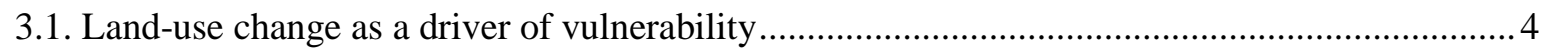

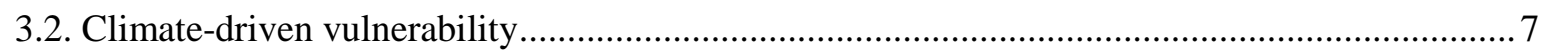

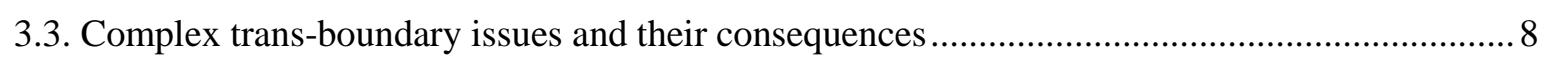

3.4. Buffering ecosystems and livelihoods with agroforestry: opportunities and challenges............. 9

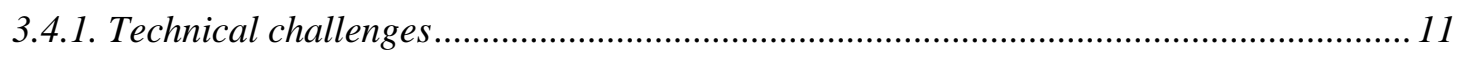

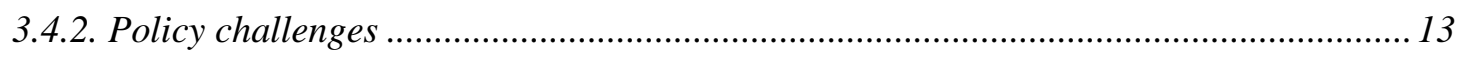

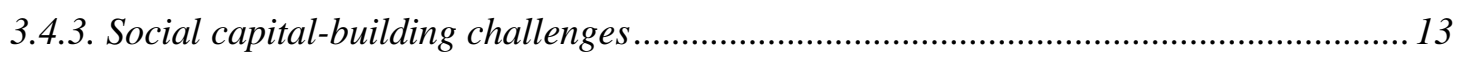

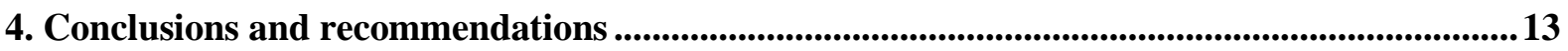

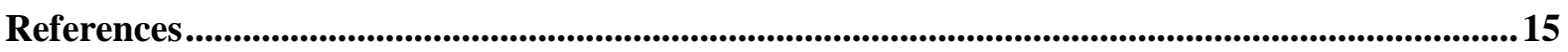





\section{Introduction}

The Lower Mekong Basin (LMB) is a trans-boundary landscape of $606,000 \mathrm{~km}^{2}$ located in the lower part of the Mekong River system. It is home to 63.5 million people in the four countries of Cambodia, Laos, Thailand, and Viet Nam, which are all members of the Mekong River Commission (MRC) (BMZ 2012). Over 80\% of the population in LMB is classified as "rural poor" with livelihoods directly dependent on the availability of rain, reservoir and/or river water for food production (MRC 2003).

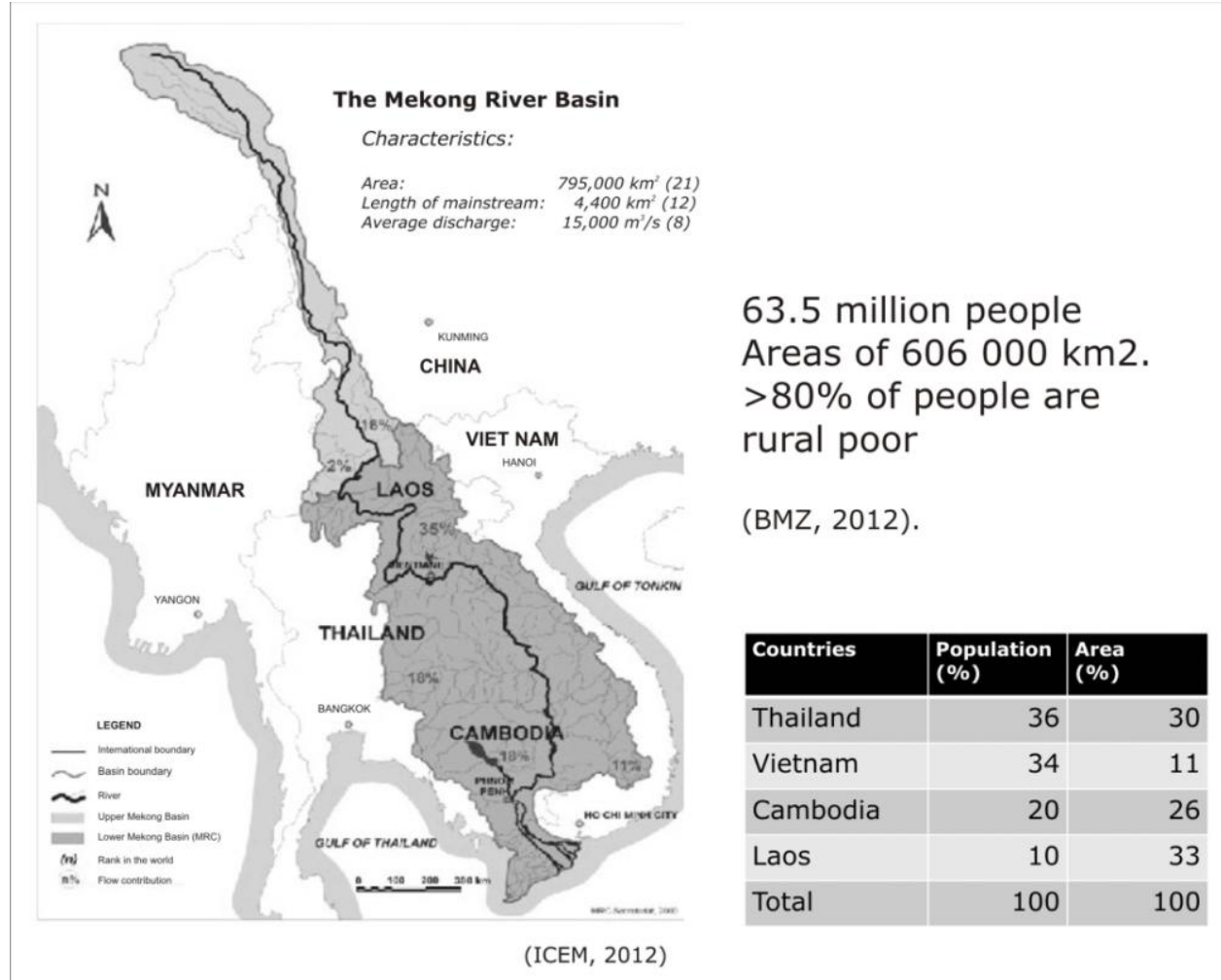

The region generates around half of the world's rice exports and provides food for over 300 million people (BMZ 2012), nearly five times its own population. Yet, the region is still rich in biological and cultural diversity, although this is under threat. The productivity and diversity of the region is threatened by increased population, deforestation and intensification of commercial agriculture driven by regional and global markets, as well as rapid expansion of urban and peri-urban areas (Fox and Vogler 2005; Grumbine and Xu 2011). The population is projected to rise to more than 82 million and the proportion of urban dwellers from about $20 \%$ today to $40 \%$ by 2030 , with economic growth at around $4.5 \%$ per year (Mainuddin and Kirby 2009). Changes in climate, including temperature and precipitation patterns, which affect sea levels and river flows, can add substantial stresses to infrastructure and especially to the food, water, energy, and ecosystems that people depend upon (NIC 2010). Despite the natural resource base of the LMB being under threat, recent debates among Mekong countries have focused on the commercial exploitation of the region's natural resources rather than the need to sustain ecosystem functions. 


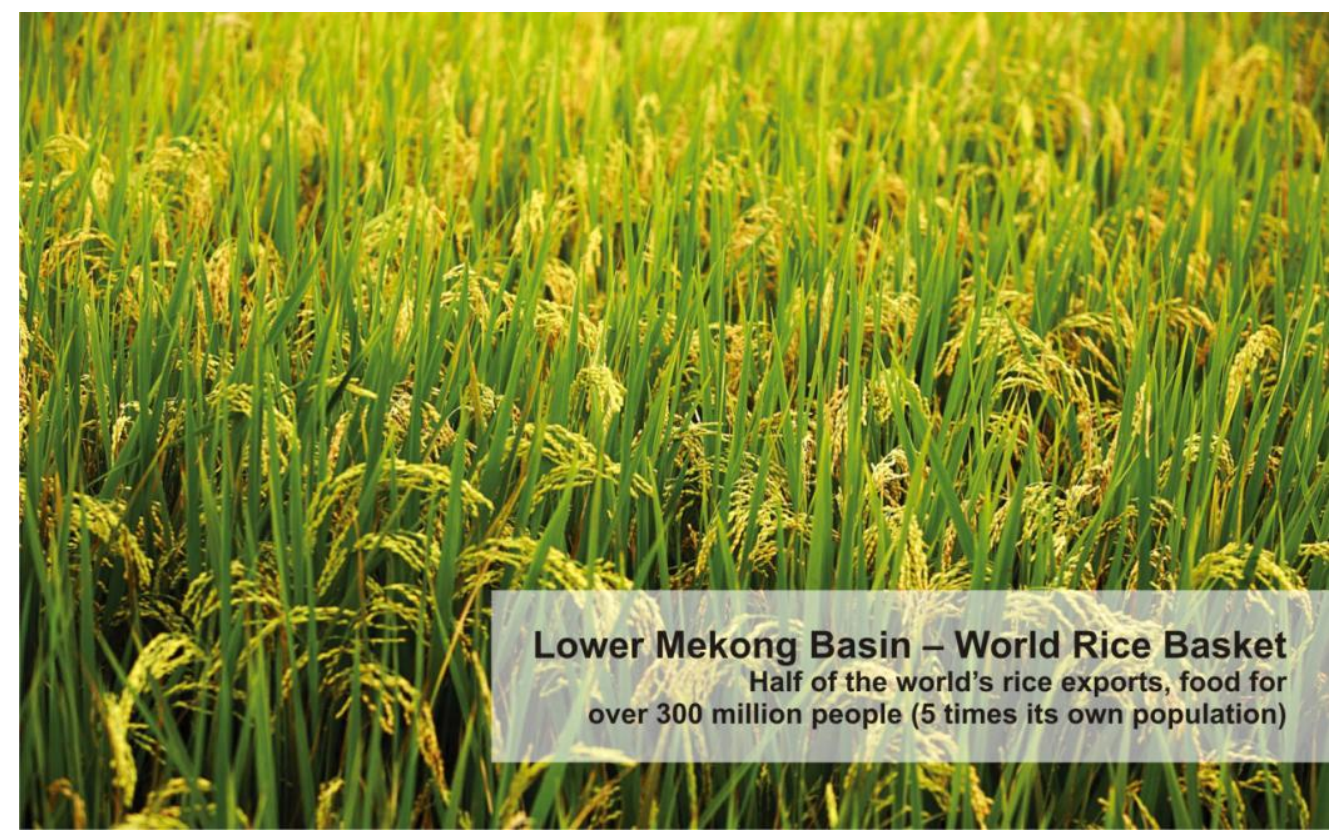

While engineering options such as dam construction have been widely pursued in LMB, green options, such as promoting conservation farming, including how to manage trees outside forests and agroforestry (combining trees and shrubs with crops and/or livestock) for enhancing ecosystem buffering, are just emerging. For a long time, trees outside forestsincluding scattered trees, farm forests, woodlots and agroforestry (AF) — have been known for their benefits in preventing soil loss through erosion, enhancing nutrient and water recycling (and thereafter enhancing crop yields), in sequestering carbon, and improving access to feed, food and fuel for smallholders in the tropics (Matocha et al 2012; Pramova et al 2012; Grandstaff et al 1986). Agro-biodiverse, intermediate-intensity agroforestry options at farm and landscape scales are likely to increase farmers' capacity to deal with economic and climatic shocks as well as natural (and human-induced) disasters (Nguyen et al 2013; Hoang et al 2013). Such practices, however, remain blind spots for much research and development because they are misunderstood as being of only "traditional" value rather than as dynamic responses to contemporary pressures that build on local knowledge and practice. Today, with the landscape approach being taken seriously in international climate debates, the role of complex land uses and forest mosaics in maintaining and building both the multifunctionality of landscapes and the diversity of livelihoods has also received renewed recognition.

In order to help identify strategies for sustainable land use in the rapid changing context of the LMB region, this paper reviews 1) the complex impacts of on-going land use and climate changes in the LMB region; and 2) the potential role of trees outside forests in helping reduce the negative impacts of the changes. On the basis of our review, possibilities and challenges in promoting trees outside forest, including agroforestry practices and systems, are discussed. We see reduced vulnerability as dependent on the maintenance of ecosystem services and the use of appropriate policy instruments at multiple scales (van Noordwijk et al 2011a; Scherr at al 2012, Harvey at al 2013). Existing peer-reviewed literature was searched using a set of keywords related to our research assumptions (Section 2 below). 


\section{Theory and methods}

In this review paper, we began with the assumption that buffering is a key part of ecosystem services provided by natural capital but that it interacts with (and is partially substitutable by) buffering provided by social capital. Lack or loss of either type of buffering implies vulnerability. We hypothesized that the trends in the LMB are a decreasing supply of buffering while demand is increasing, with uncertainty related to climate, global markets, etc. We then analyzed current trends, impacts and potential roles of trees outside forests in enhancing buffering by reviewing existing peer-viewed literature searched on a set of relevant keywords, along with review of relevant unpublished data on land use and livelihood transitions of the Mae Chaem catchment in Northern Thailand. On the basis of these reviews, we revisited the hypothesis and its policy implications.

We adopted an interdisciplinary framework that views the LMB as a dynamic socioecological system (Folke 2006). Systems linking people and nature, known as socialecological systems, are increasingly understood as complex adaptive systems (Levin et al 2013). Governance of trans-boundary issues becomes increasingly important as we move from individual livelihoods through to larger landscape units. Vulnerability of lives and landscapes within the LMB were analyzed using an Earth system approach (Steffen et al 2004). This focuses on connections amongst climate-system components-including regional atmospheric circulation, land cover and hydrology - with national and local socio-economic systems. We assumed that changes in climate variability and land use interact strongly with the evolution of socioeconomic systems and infrastructure in the region and can either exacerbate environmental problems or, if anticipated and prepared for, create opportunities to establish more sustainable socio-ecological management (Cruz et al 2007; ADB 2009; NIC 2010).

In the context of this paper, "resilience" and "vulnerability" are opposing, multidimensional concepts that refer to the ability of people and landscapes to cope with variability (both natural and as a result of human disturbance) and adapt to change, including change in variability. Lives and landscapes become vulnerable when they are pushed beyond comfort zones, for example, through collapse of key buffer and filter functions that shield and sustain them. The concepts of "buffers" and "filters", as used here, are related. Buffers reduce variability, while filters (selectively) reduce transmission. Technical definitions of "buffer" are indeed based on variance reduction. For example, stream flow is buffered, although still variable: if it would be the same amount every day buffering would be $100 \%$. The concept of buffering applies to anything that varies in situations where variation matters: prices, rainfall, temperature, politics, human health in the face of diseases, crop health in the face of pests, soil water content, etc. Buffering cannot, however, shift mean values over a longer time period. In the context of landscape analysis, buffers and filters are most commonly related to water flows and erosion/sedimentation processes. Strips of land along river banks, or in other strategic positions in a landscape, which have a filter function can be called "filters" themselves. The term "buffer" is often used as a shortened term for "buffer zone", an area inbetween intensive agriculture and areas for conservation of natural habitat and associated biodiversity. The buffer zone is intended to buffer human influence on wildlife and wildlife influence on humans (van Noordwijk et al 2011a).

In the context of ecosystems, the buffering capacity of ecosystem state variable $X$ with respect to $\mathrm{Y}$ is defined as the ratio of variance in $\mathrm{X}$ to the variance in forcing function $\mathrm{Y}$ (Jorgensen 1997; van Noordwijk et al 2011a). Forcing functions are defined as external variables that potentially influence ecosystem behaviour, whether natural or anthropogenic 
(Rutger at al. 2001). Buffering capacity varies with the forcing functions considered, but the most salient ones are those that, after accounting for all available buffering effects, have the strongest impact on system behaviour. "Robustness" refers to a system's ability to continue to function when intrinsic and extrinsic disturbances occur. "Resilience" can go beyond robustness and include the ability to reorganize after being challenged (Levin 1998; Levin and Lubchenko 2008; Folke et al 2010). Buffering of human lives and livelihoods from climatic variability is an important ecosystem service, but it depends on the resilience of the components that provide the buffering. A livelihood is resilient if it can maintain its key functions (e.g. physical security, food, safe water, income, etc.) and absorb the impact of disturbances without undergoing major decline in production and well-being (Speranza 2013).

\section{Results and discussion}

\subsection{Land-use change as a driver of vulnerability}

During the last decade, the agricultural frontier in LMB has advanced into areas of remaining forest as demand for land and resources has increased both from growing populations within the region and to meet demands from outside (Fox and Vogler 2005). The commercialization of agriculture and its promotion by LMB governments is driving land-use change towards more cash crops such as rubber, coffee, cashews, and fast-growing wood species for pulp and paper, as well as toward higher cropping intensities (Rowcroft 2008; Hall et al 2011).

Between 2000 and 2010, the area of land occupied by tree crops grew at an annual rate of 4.3\% (Li and Fox 2011). In upper watershed areas of the LMB, changes in land-use patterns during recent decades have been closely associated with transitions from traditional forestfallow shifting cultivation of upland rice, which incorporated a diverse array of minor subsistence crops, into fixed-field intensive production of upland rice and cash crops. How this transition progressed during 1989-2008 in a major upper tributary catchment of the Ping River Basin in northern Thailand can be seen in the following diagram constructed from data in neighbouring Mae Chaem (Figure 1). Although timing and types of commercial crops vary by location, basically similar types of processes have been occurring in mountain zones of the LMB. 


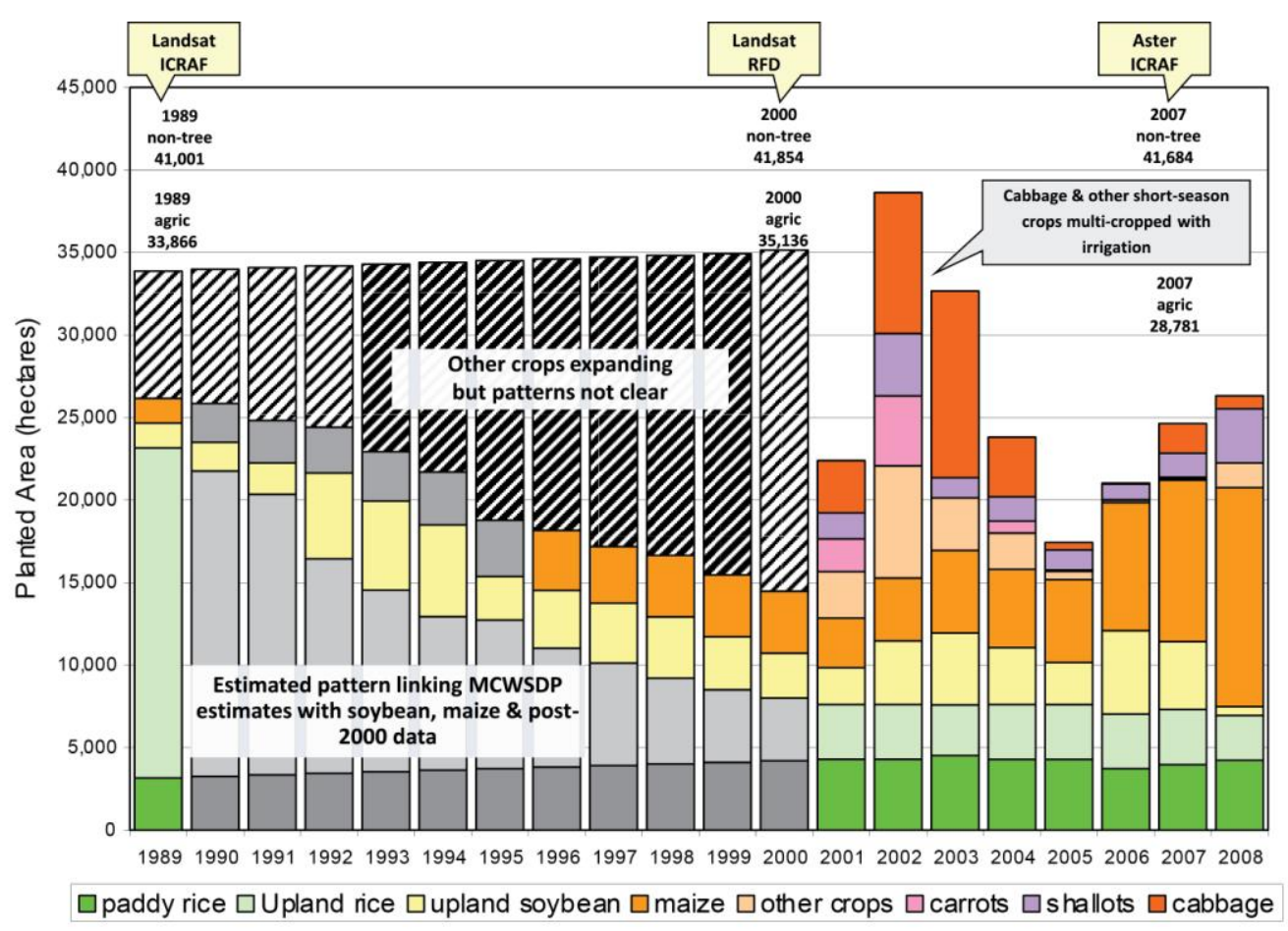

Figure 1. Mae Chaem crop and livelihoods' transitions, 1989-2007

Note: MCWSDP = Mae Chaem Watershed Development Project (source of data for 1989) [note: other crop data from local district agriculture office]; RFD = Royal Forest Department (conducted official interpretation of 2000 Landsat data); ICRAF = World Agroforestry Centre (conducted official interpretation of 1989 Landsat and 2007 Aster data)

In addition to the perceived impacts of commercial boom crops, increased concern for environmental conservation has led state actors to zone large amounts of land as off limits to agriculture and, increasingly, to try to enforce that zoning. In the LMB as a whole, almost a quarter of the land area (22\%) is demarcated for conservation, which is the largest proportion of any region of the world (PADP 2003). Despite this, the forest transition is still proceeding rapidly (Meyfroidt and Lambin 2009). Forest cover in mainland Southeast Asia fell from 51 to $46 \%$ between 1990 and 2010 as a result of losses in Thailand, Cambodia, Laos and Myanmar. While overall population pressure has been a major determinant of past deforestation in Cambodia and Thailand, a strong correlation between poverty and environmental degradation (deforestation and soil degradation) was identified in Laos (Dasgupta et al 2005). This deforestation has been linked to related environmental problems such as floods, siltation, and damage to aquatic habitats.

The number of trees outside forest increased: In Thailand, the agricultural frontier has halted and forests are beginning to regrow on former cropland, while in Viet Nam large, government-supported afforestation and reforestation programs are resulting in forest expansion. In northeastern Thailand, various types of tree plantations are replacing upland crops that first followed deforestation. For more mountainous areas, Thomas and colleagues compiled a picture of forest-cover change during an 18-year period (1989-2007) in a major upper tributary catchment in northern Thailand by analyzing a time series of Landsat 5, 7 and Aster images of Mae Chaem (Figure 2). This analysis indicated maintenance of a similar percentage of forest cover (87\%) during the entire period, but it was changing into a much more segregated pattern. Moreover, forest characteristics changed with state agency programs 
to stop forest-fallow shifting cultivation, thus forcing agriculture into intensive fixed-field cultivation dependent on purchased inputs. A somewhat similar pattern can also be found in Viet Nam, as despite reported increased forest cover in the country, low-quality forest and continued deforestation for resettlement and cash crops still occurs in the Central Highlands (Hoang et al 2011). These changes reflect tree-cover transitions observed elsewhere in Southeast Asia: forest decline followed by later expansion of tree cover on agricultural land.

According to Garrity (2012), tree cover on farms in Southeast Asia exceeds 30\%. It is anticipated that this trend may continue in LMB in coming decades due to population increase, urbanization and economic growth (Mainuddin and Kirby 2009). A recent strategy for mountainous northern Laos proposes that agriculture-forest segregation should be buffered in such a way that a diversity of livelihoods' opportunities and economic development pathways can be maintained (Castella et al 2013).
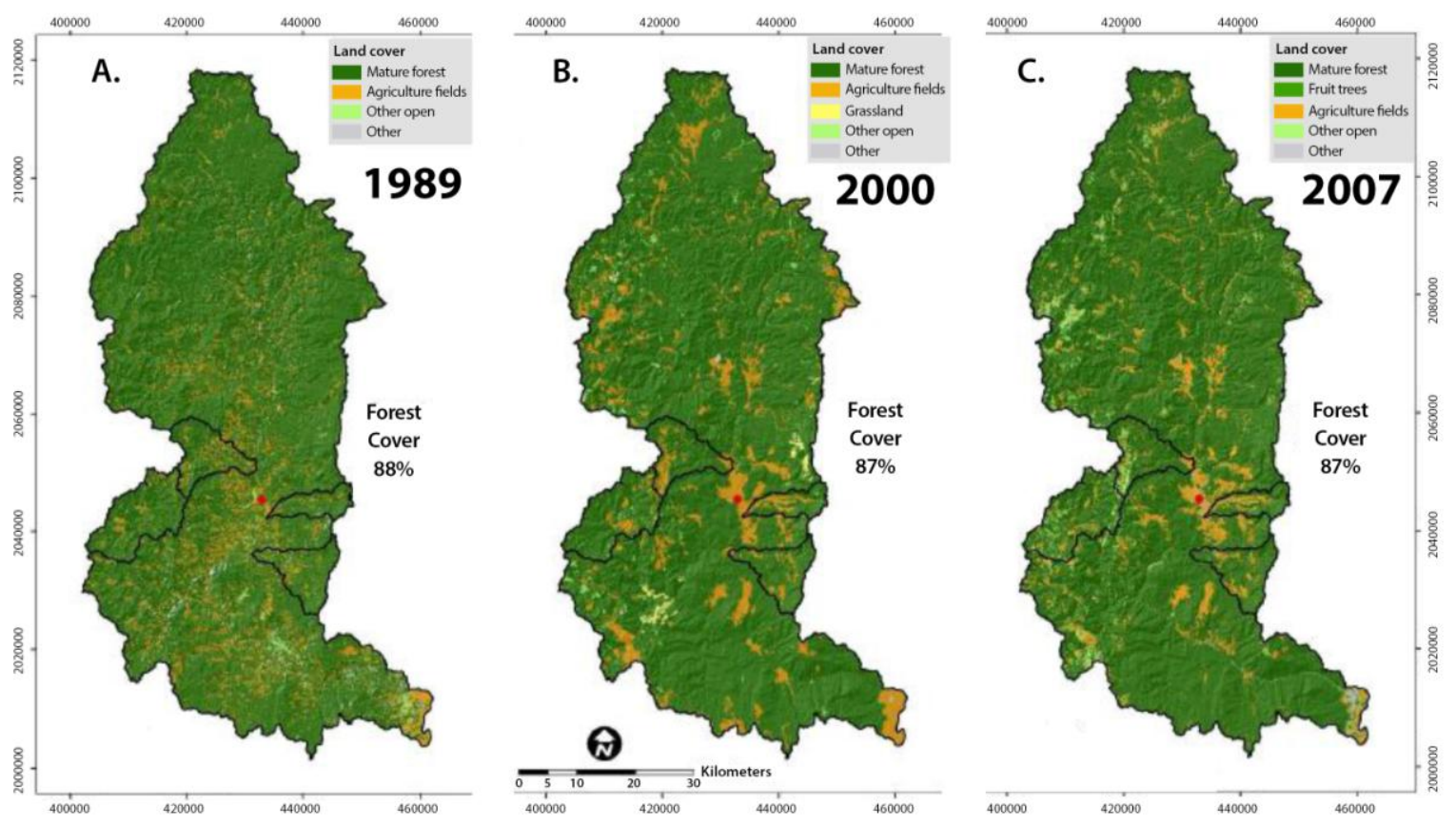

Figure 2. Overall land-cover change in Mae Chaem, 1989-2007

More intensification in agricultural land: Intensification of the $40 \%$ of the LMB area used for agriculture is the second important trend. Rain-fed rice accounts for about $80 \%$ of the total production of annual crops in the region but is being progressively intensified through use of supplementary irrigation and increasing fertilizer input (Mainuddin et al 2012). Crop and land-cover change shown in Mae Chaem is a clear example of this trend toward intensification even in mountainous upper tributary areas (Figures 1 and 2).

Modelling results suggest that current development of dams for irrigation and hydropower plants in upstream China and on Laotian tributaries will reduce flows downstream, particularly during the dry season, which will neither satisfy requirements for downstream irrigation nor prevent saltwater ingression in the delta (MRC 2004; Pech and Sunda 2008). The direct downstream costs of the dams through reducing fisheries, inundation of riverbank gardens and loss of nutrients for floodplain agriculture has been estimated at USD 500 million/year (Grumbine and $\mathrm{Xu}$ 2011). There is, however, another way to increase the productivity of rain-fed agriculture without high water consumption. According to 
Mainuddin and Kirby (2009), Rain-fed crop productivity in the LMB can be increased by replacing crop varieties and improving management practices, including agroforestry.

The challenges in promoting trees outside forest to enhance the buffering capacity of ecosystems and livelihoods in the LMB are discussed later in this paper.

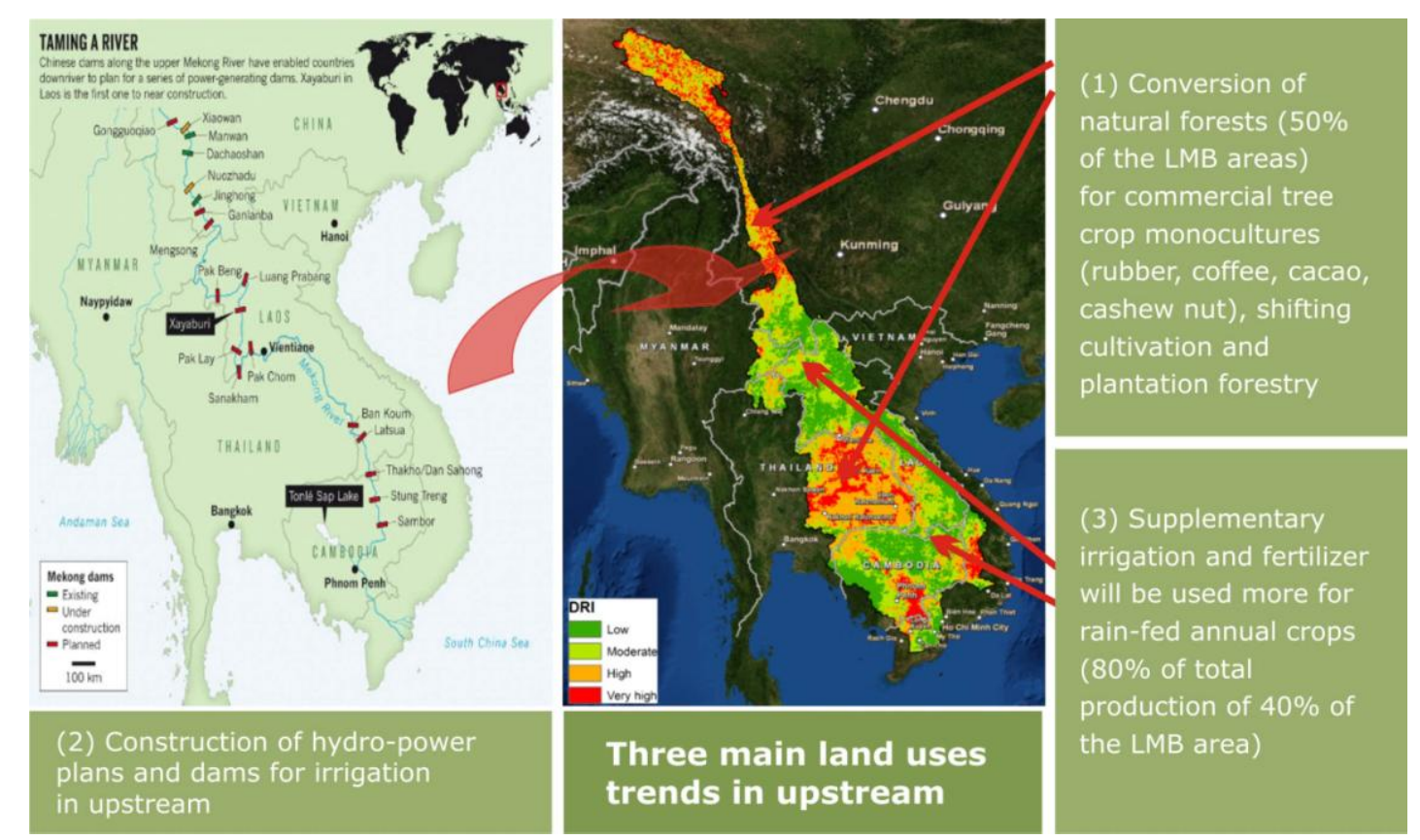

\subsection{Climate-driven vulnerability}

The monsoon regime dominates atmospheric circulation in mainland Southeast Asia, including the LMB, resulting in highly seasonal precipitation, with $80-90 \%$ of total precipitation falling during the six-month summer monsoon (approximately May-October). The time of onset, duration, intensity and frequency of breaks in the summer monsoon's circulation and precipitation can vary significantly, resulting in a relatively high frequency of extreme precipitation years, both low and high. Drought owing to deficient monsoon rainfall can produce widespread crop failure and famine. Global climate change is expected to have significant effects on the Asian monsoon circulation with consequences for the mean and variability of regional climate in the region. Expectations are that climate warming will cause intensification of the monsoon, resulting in greater inter-annual and multi-decadal variability in the form of more frequent and more severe droughts and floods (Overpeck and Cole 2007). Upward trends in temperature and the frequency of high temperature extremes have been detected in the region; significant rain days have decreased in number and the proportion of annual rainfall derived from extreme events has increased (Manton et al 2001). Observations indicate that a shift toward a drier climate in the region began in the mid-1970s (Cook et al 2010), along with a weakening of the relationship between the El Niño-Southern Oscillation and the Asian monsoon (Ummenhofer et al 2011). In the LMB, the dry season is expected to lengthen and intensify, and the rainy season is expected to shorten and intensify, with dramatic increases in rainfall in the wettest months. Thus, both seasonal water shortages and floods may be exacerbated, as may saltwater intrusion into the Mekong Delta (Mainuddin and Kirby 2009). Furthermore, sea-level rises owing to climate change are projected to affect a 
minimum of $69 \%$ of the delta by 2030 and virtually all of it by 2070 during the flood season (Bindoff et al 2007).

Indeed, changes in climate and land use interact strongly with the evolution of socioeconomic systems and infrastructure in the region. Together, they seem to exacerbate environmental problems, which threaten the resilience of ecosystems and livelihoods at farm and landscape scales.

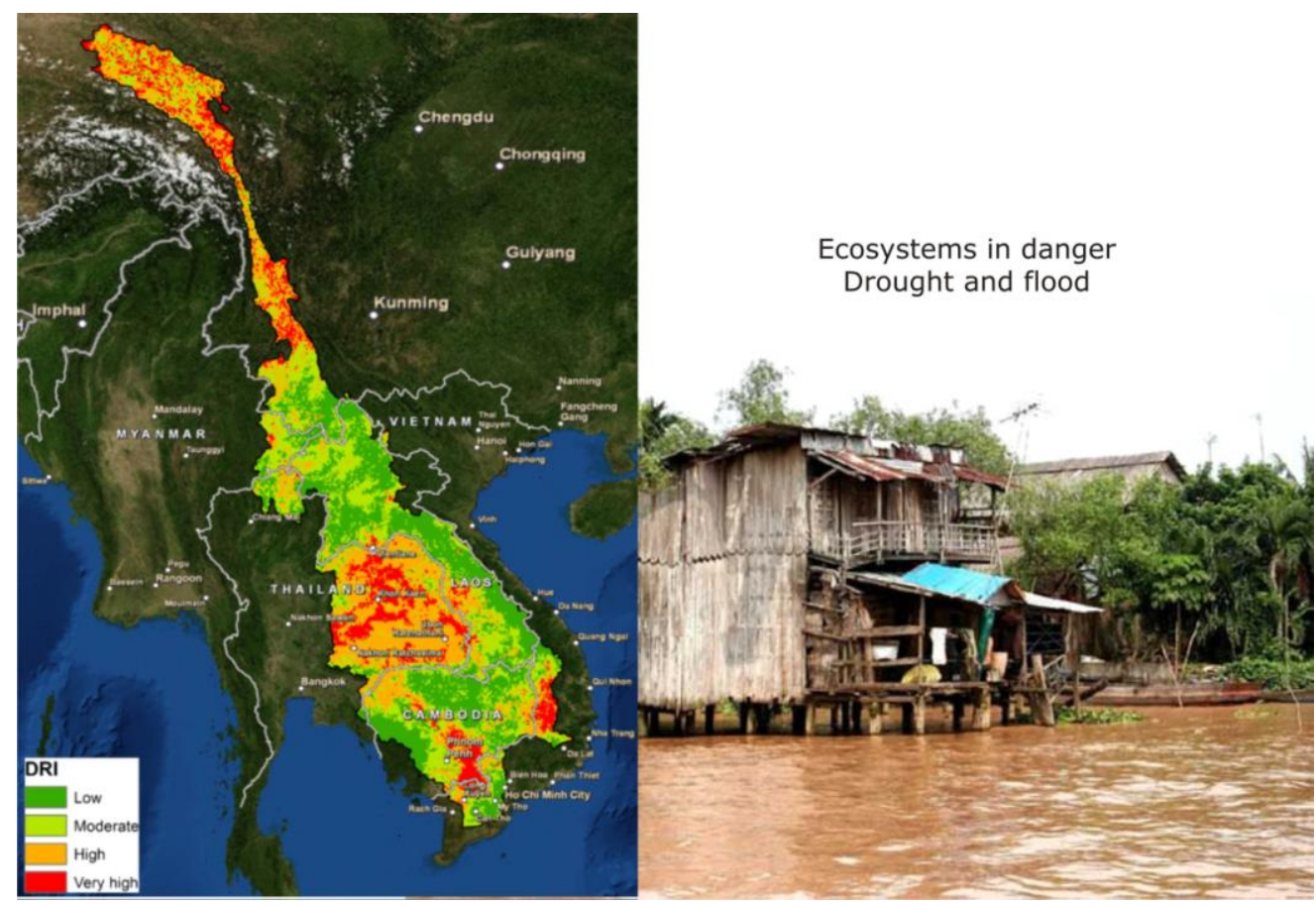

\subsection{Complex trans-boundary issues and their consequences}

More severe drought and flooding because of water abstraction and monoculture: More intensification of rain-fed annual crops and increased areas of commercial tree crops will both require more off-season water for cultivation. A projected drier climate with increased rainfall variability makes water supply less predictable. An increased buffering of water is thus needed, but the actual buffering capacity of landscapes is declining because of reduction of forest and riparian wetlands and increased erosion from monoculture cultivation of crops on sloping land (Bradshaw et al 2007; FAO 2008). Technical approaches for increasing buffering through construction of dams and reservoirs also use water for hydropower generation and downstream irrigation, frequently leaving little capacity to absorb unexpected rainfall towards the end of the rainy season, as was seen in the 2011 Bangkok floods: reservoirs in North Thailand had no storage capacity left because their operational rules prescribed maximum water supply for the dry season. Total economic costs were huge (Cook et al 2010). Pech and Sunada (2008) suggest that, in order to satisfy requirements for further irrigation expansion in the LMB and to prevent seawater intrusion into the Mekong Delta, flow needs to be generated during the critical dry months, either from points above Kratie or from Tonle Sap Great Lake. However, modelling results generated by the Mekong River Committee (2004) show that development of Chinese dams and six dams on Laotian tributaries will have the effect of reducing flows beyond even the standard deviation of wet and dry years (estimated to be around 23\%) at Kratie. Data from 15 years (1994-2008) of 
paired catchment water observations in the upper part of the Mekong River Basin in Xishuangbanna, China, showed that soil-water storage during the rainy season was not sufficient to maintain the high evapotranspiration rates of rubber plantations, resulting in zero flow and water shortages during the dry season (Zheng et al 2012). Reducing drought risk during dry seasons and years, and floods during wet months, requires technical plus natural buffering to secure downstream ecosystems and livelihoods.

Reduction of biodiversity: The increasing prevalence of monocultural practices on land that used to have agrobiodiverse land uses reduces biological buffering of pests, weeds and diseases and increases risk to farmers in the face of climate variability and market fluctuations (Foley et al 2005; Tengo and Belfrage 2004). Furthermore, conservation of plant richness is important since plant diversity provides floral resources, alternative hosts that help support pollinators, natural enemies, soil quality and yield stability (Egan and Mortensen 2012). Moreover, it is one of three key sources for tree diversity in an agricultural landscape (Ordonez et al 2013).

Erosion and depletion of soil organic carbon: Intensification of crop monocultures and Rain-fed rice or maize on steep slopes can cause serious erosion. When the soil's surface layer is washed away the subsoil is exposed, which has lower soil organic carbon content and water-holding and infiltration capacity. This further increases surface run-off. Groundwater dynamics are also affected by dry-season water use, for example, by rubber plantations in the upper part of the Mekong River Basin (Zeng et al 2012).

Long-term impacts and complexity at landscape scale: It usually takes some time before unintended effects of human changes in agro-ecosystem functions can be seen. This is because interactions involve lag times before ecosystem resilience reaches a tipping point. For example, irrigation of a commercial agricultural landscape was found to have adversely affected water quality and quantity in the delta of the northwestern Mississippi only after 20 years of monitoring (Coupe et al 2012). More severe dry season droughts due to expansion of rubber monocultures in the Upper Mekong Basin were only confirmed after 15 years of systematic observation (Zeng et al 2012). Moreover, policies aimed at one sector in one part of the LMB may cause unintended ecological consequence in other sectors and places (Coupe et al 2012).

Livelihoods' vulnerability: Commercialization of agriculture and more intensified cropping in LMB make local farmers more exposed to volatility of external markets. Smallholding farmers, with no savings or insurance, are particularly vulnerable when prices of agricultural products drop and/or prices of irrigation, fertilization and/or other inputs increase.

\subsection{Buffering ecosystems and livelihoods with agroforestry: opportunities and challenges}

Different tree-based land uses are more or less useful in providing multifunctionality in products and soil-related ecosystem services, depending on species, management, and location in a landscape (Table 1). In addition to the buffering effects listed, examples show that land-use practices also contribute to climate mitigation through increasing carbon storage in biomass and soil; by reducing pressure on natural forests if in buffer zones (example 2); by reducing soil carbon losses through erosion on sloping land and reducing the use of nitrogen fertilizer thanks to nitrogen-fixing species (example 3; Table 1). Examples of the benefits of tree-based land use appear to be captured mainly at field and farm levels, but as Willemen et al (2013) suggest, there has been "little assessment of tree-based ecosystem approach benefits 
relative to other land uses in the landscape, of interactions among land uses, or of patterns of tree-growing and impacts across the landscape".

Table 1. Examples of "win win" situations with trees and shrubs outside forests in different major agroecosystems of the Southeast Asian region

\begin{tabular}{|c|c|c|c|}
\hline $\begin{array}{l}\text { AF practices } \\
\text { (example number) }\end{array}$ & $\begin{array}{l}\text { Water, climate and } \\
\text { biodiversity buffering }\end{array}$ & Economic buffering & Reference \\
\hline \multicolumn{4}{|c|}{ Shade trees in perennial crops and high-value species in buffer zones in the highlands } \\
\hline $\begin{array}{l}\text { Shade trees as components } \\
\text { of rubber, coffee and cocoa } \\
\text { in Indonesia (example 1) }\end{array}$ & $\begin{array}{l}\text { Improved water retention and } \\
\text { filtration; improved resilience } \\
\text { of crop to drought }\end{array}$ & $\begin{array}{l}\text { Rubber, coffee and cocoa } \\
\text { provide important income } \\
\text { to smallholders and the } \\
\text { country }\end{array}$ & $\begin{array}{l}\text { Nyhus and Tilson } 2004 \\
\text { Sunderlin and Resosudarmo } \\
1996\end{array}$ \\
\hline $\begin{array}{l}\text { Agroforestry in buffer } \\
\text { zones in Southeast Asia }\end{array}$ & Enhanced biodiversity & $\begin{array}{l}\text { Provide higher productivity } \\
\text { and income per unit of land }\end{array}$ & $\begin{array}{l}\text { Nyhus and Tilson 2004, } \\
\text { Sekhar } 2007\end{array}$ \\
\hline
\end{tabular}

(example 2)

Legume species and bamboo in crops on sloping land

Legumes used as fallow and hedgerow species in upland rice fields in northern Viet Nam (example 3)

Bamboo in the northern central uplands of Viet

Nam (example 4)

Home and forest gardens in coastal areas

Home and forest gardens in Enhance biodiversity the central coastal zone of

Viet Nam (example 5)

Reduce erosion and water runoff;

improved water infiltration

Provide micro-climate

Fruit trees in perennial

Rubber agroforests in

Indonesia; rubber

intercropped with high-

value fruit (durian and oil

palm) in southern Thailand

(example 6)

Trees in paddy fields in central Laos and Northeast

Thailand (example 7)
Improved soil fertility, micro-

climates, providing shade

\author{
Adaptation to extreme weather \\ events \\ rovide diversified \\ products, adapt to market \\ fluctuations
}

Hoang et al 2001

Hoang et al 2002 upland rice yields after improved fallow using legumes

Create alternative, off-farm, income-generating activities

Ly at al. 2012

Food security when annual Nguyen et al 2013 crops fail due to flooding and drought
Increased firewood accessibility, livestock fodder, human food and medicines

\author{
Kosaka at al. 2006 \\ Grandstaff et al 1986
}

Simien and Penot 2011

Despite the multiple values, the complexity of designing and managing AF practices and lower outputs from AF components often makes AF less attractive compared to intensified monocultures. Furthermore, concerns exist about losing crop land to trees, which makes mainstream agricultural policymakers reluctant to encourage incorporation of more trees into agricultural landscapes. This perceived trade-off between market-oriented agriculture and economic and ecological resilience today typically leads to changes in land use away from subsistence and local food production. Sustainable intensification of agriculture is an emerging and evolving concept (Godfray et al 2010) that may possibly marry development and implementation of multifunctional and biodiverse agro-ecosystems, including woody perennial crops and trees, with more highly productive and entrepreneurial farm management (Bommarco et al 2012). As a result, total production would not need to decline despite allocation of some land use for trees. Furthermore, landscape planning and monitoring can 
help map and assess ecological and economic interactions between trees and crops over time and space, and thus stimulate adoption of AF (Example 5, Table 1). Several challenges and research questions raised below may help further sharpen the research and development agenda for $\mathrm{AF}$ in the $\mathrm{LMB}$.

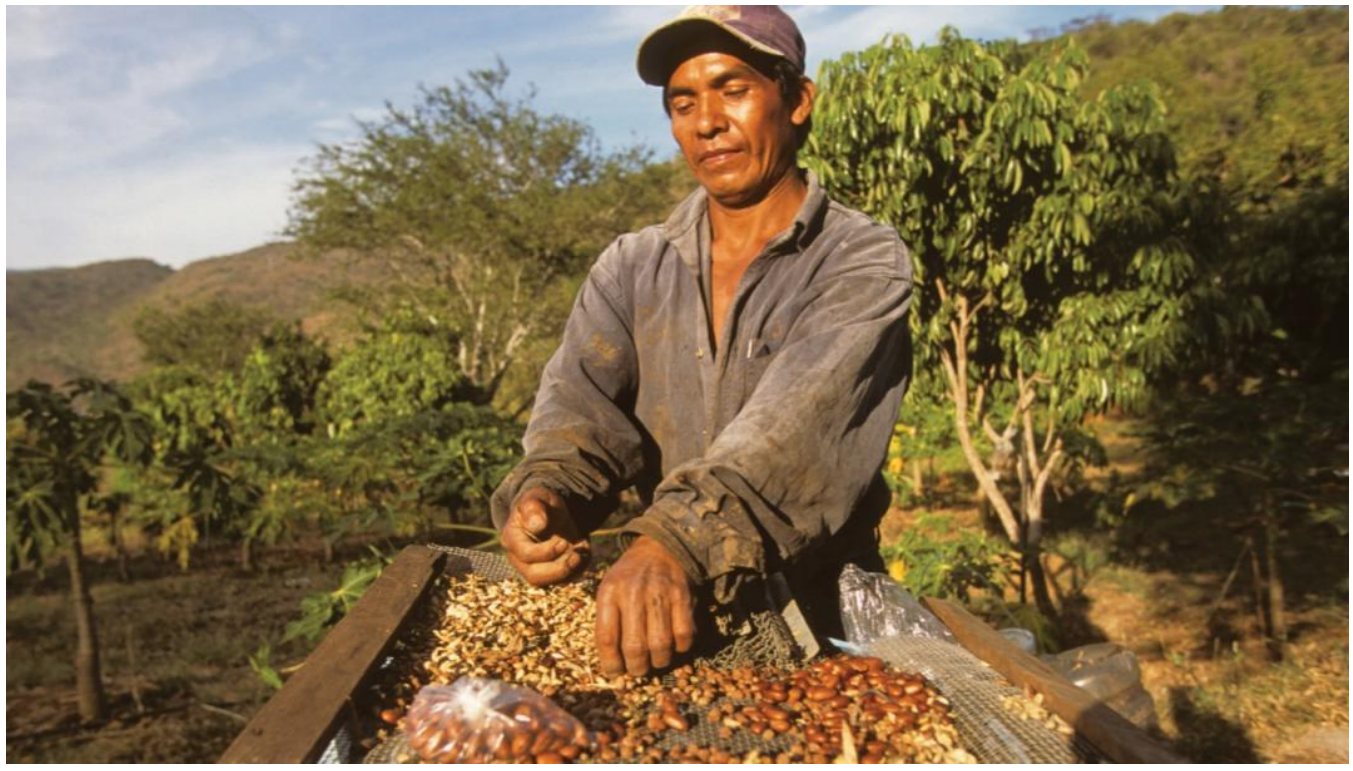

Converting mono-cropping of commercial tree crops (rubber, cache nut, coffee) to multi-strata or parkland agroforestry by inclusion of suitable species in current plantation

\subsubsection{Technical challenges}

Suitability of trees and agroforestry practices for helping buffer ecosystems and livelihoods is related to the multifunctionality they can provide. Farmers' preferences, tree and site matching, seed dispersal, tree domestication and delivery via nurseries all play important roles in determining tree diversity (Ordonez 2013). Farmers are often well aware of functionality and manage different species for different purposes, related to how trees affect crops, ecosystem processes and more importantly how trees contribute to their livelihoods (Idol et al 2011), especially when crop failures are due to climate variability (Hoang at al 2013a). At field level, one key role of AF science is to accumulate local knowledge in a systematic way and use it in simulating potential environmental services and yield impacts of different techniques for managing trees and their interaction with crops. Tools to accomplish these tasks are particularly important for developing sustainable intensive agroforestry and agricultural practices. A good example of one such tool is the model named Water, Light and Nutrient Capture in Agroforestry Systems (WaNuLCAS, van Noordijk 2011b). At farm level, the potential economic impacts of AF practices is one of the most decisive factors affecting farmers' adoption, and farming system analysis is a good assessment tool.

Roles of trees as buffers and filters for water and soil flows, for biodiversity, and for economic returns over time and space need to be seriously considered in agricultural landscape planning and monitoring. This can start by identifying "hot spots" of change or vulnerability through the characterization and spatial mapping of land use and land-function changes. From that, priority areas for intervention and context-specific investment opportunities and options with trees and AF practices can be defined. A proper representation of land function in many cases can only be achieved at local scales of analysis (Verburg 2009). For this purpose, a package of methods and tools, which are integrated in a participatory modelling approach, is recommended at a watershed level. These tools include 
participatory mapping and role-playing games (Villamor at al. 2011); an agent-based model (Villamor 2012); development of meso-level, land-use-planning scenarios from multistakeholder discussions, governments' development plans, mitigation plans etc and projection of future land uses based on the scenarios using the Forest, Agroforest, Low-value Landscape or Wasteland (FALLOW) model (Lusiana et al 2011, 2012) for the entire landscape.

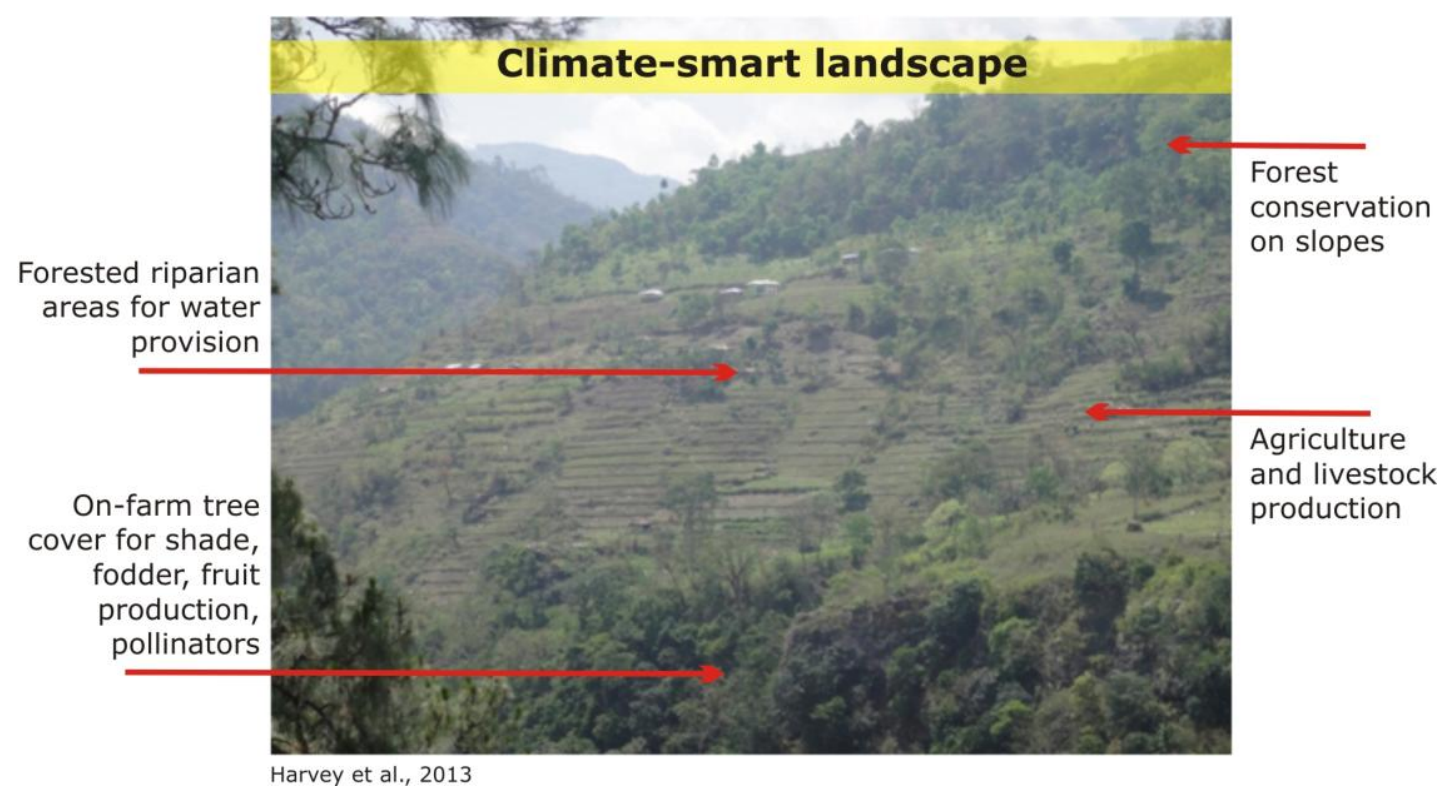

Appropriate combinations and spatial arrangements of suitable trees and agroforestry practices is needed in order to maximize synergies and to reduce trade-off among different ecosystem services as well as between climate-change adaptation and mitigation (Harvey et al 2013). More research is needed on 1) the balance between how trees improve soil quality and infiltration and the same trees' consumption of water; and 2) trade-offs between carbon sequestration and water consumption/provision by the same tree. In order for forests and trees to contribute to conserving base flows, increased water infiltration in soils induced by trees must be greater than their water consumption (Viglizzo et al 2012). Furthermore, carbon accumulation based on increasing net primary production rates may simultaneously cut catchment water yields and, hence, water provision. Such potential trade-offs show the importance of considering soil properties and management when assessing benefits of different tree-based land uses (Pramova 2012) at nested scales.

Identifying indicators of links among environmental services may help in assessing and promoting synergies. Soil carbon plays a vital role in regulating climate, water supplies and biodiversity, and thus in providing services that are essential to human well-being (UNEP 2012). A survey of soil carbon in Laos found that the largest stocks of soil organic carbon are under forests, followed by forest-fallow shifting cultivation, while the smallest are under continuous monocropping (Chaplot 2010). Systematic review and meta-analysis of effects of afforestation or planting trees in agricultural areas showed a change in infiltration capacity of approximately three-to-four times (Ilstedt et al 2009). Thus, further research is needed to clarify prospects of soil carbon as a combined indicator of environmental services at nested scales. Other challenges are the site-specific nature of agroforestry and the lack of uniform methods to estimate carbon sequestration, making it difficult to compare results and expand from site to landscape level. There is even less empirical data on the impact of adding trees on balances among water use, water run-off, evapotranspiration, and water infiltration 
capacity, with primary empirical studies being greatly outnumbered by narrative reviews and policy-related reports and discussions (Malmer et al 2010).

\subsubsection{Policy challenges}

Creation of policies aimed at redirecting development pathways by integrating natural resources integrity is recommended for promoting agroforestry research and development. For example, combining incentive systems - including payments for watershed functions and carbon provided by trees, as well as support for poverty reduction-together with income from tree products will theoretically be sufficient to cover opportunity costs of monocultural agriculture or forest conversion in the uplands of northern Viet Nam (Hoang at al 2013b). According to Namirembe et al (2013), co-investment in stewardship together with secure rights is a more widespread and versatile approach for a variety of environmental services. In terms of tools to help support policy decision-making, analysis of trade-offs can help assess relative responses of individual social and economic indicators on the one hand, together with estimates of ecosystem services on the other, per unit of land-use change (Viglizo et al 2012). Another potential policy approach is based on compensation mechanisms to more equitably distribute costs of watershed management. For example, opportunity costs linked to forest conservation upstream can be compensated by payments for environmental services (WertzKanounnikoff et al 2011). A major challenge is how to overcome commodity issues for environmental services, related to elites and corruption, which lead to inequality among land users (Gómez-Baggethun at al 2011). Institutional failures that erode resilience are brought about by lack of rule enforcement and corruption (Bingeman et al 2004). Thus, policy reforms by government agencies must consider strategies for designing participatory approaches and co-interest incentive schemes at farm scale in order to help alleviate the sustainability issues of agricultural landscapes (Kumaraswamy 2012).

\subsubsection{Social capital-building challenges}

In addition to appropriate policies and sufficient funding, several more socioeconomic factors are needed to effectively promote agroforestry and trees outside forests. Among them, participation by communities in decision making through enhancing advocacy (Sneddon and Fox 2007), access to markets and credit, investment costs, institutional capacity, and land and tree tenure (Harvey et al 2013) are all known to affect adoption of AF practices. Combining monitoring systems at different levels (local, landscape, regional) will provide a rich set of information on feedbacks and dynamics in socio-ecological systems. Involving stakeholders, especially the beneficiaries of ecosystem services, in the monitoring process will enhance overall adaptive capacity, incentives to learn, and the delivery of early warnings related to environmental change. These factors, along with improved communication of Mekongrelated information in all riparian languages are only some of the challenges urgently needing attention. The main challenge lies in creating enabling conditions and processes for innovation, flexibility, and iterative and incremental learning (Viglizo et al 2012).

\section{Conclusions and recommendations}

Vulnerability of ecosystems and people in the LMB is seen through four regional transboundary issues, including 1) more severe drought and flooding linked with water abstraction 
and land-use change; 2) reduced biodiversity; 3) increased erosion and depletion of soil organic carbon; and 4) greater long-term impacts and complexity at landscape scales. The close interaction among these four trans-boundary issues in time and space justify a recommendation for more holistic, nested, landscape and policy approaches to solving problems.

Trees outside forests are useful in providing ecological and economic buffering, depending on species, management, and location in a landscape. Sustainable intensification of agriculture, including highly productive woody perennial crops and trees together with entrepreneurial farm management, are needed to help to make AF practices attractive to farmers.

The lack of assessment of benefits from tree-based land use relative to other land uses in the landscape justifies our recommendation for further research. Assessments need to focus on both ecological and economic interactions between trees and other land uses over time and space, especially during the most harsh climate conditions, such as flooding and drought. Combining local knowledge and scientific knowledge (modelling, farming system analysis, landscape analysis, trade-off analysis) in selecting optimal combinations and spatial arrangements of suitable trees and agroforestry practices is necessary in order to maximize synergies and reduce trade-offs among different ecosystem services, between ecosystem benefits and economic benefits, and between climate-change adaptation and mitigation purposes. The prospect of soil carbon as a combined environmental service indicator at nested scales, and the lack of required empirical data, result in a clear need for further research.

Creation and modification of policies to redirect development pathways through integrating natural resources integrity is recommended for promoting agroforestry research and development. We recommend that policymakers pay particular attention to strategies for participatory approaches and co-interest incentive schemes at farm scale to alleviate the sustainability issues of agricultural landscapes.

Several socioeconomic factors are clearly required for effective promotion of trees outside forests and agroforestry. Recommendations include appropriate enhancements of agroforestry advocacy, access to markets and credit, public investments, institutional capacity, land and tree tenure, and nested levels of monitoring systems with high involvement of stakeholders, particularly beneficiaries of ecosystem services.

Comparative assessments of current and future socio-economic and environmental impacts of tree-based strategies, in contrast to "business as usual" strategies are recommended to provide a base for informing decisions and mediating trans-boundary negotiations. This strategy is in line with the green economy that is currently considered an important direction for development in global agriculture. 


\section{References}

ADB. 2009 The economics of climate change in Southeast Asia: a regional review. Asian Development Bank, Manila, Philippines.

Bindoff NL, Willebrand J, Artale V, Cazenave A, Gregory J, Gulev S, Hanawa K, Le Quéré C, Levitus S, Nojiri Y, Shum CK, Talley LD, Unnikrishnan A. 2007. Observations: oceanic climate change and sea level. In: Solomon, S, Qin, D, Manning, M, Chen, Z, Marquis, M, Avery K.B, Tignor, M, Miller HL (eds) Climate change 2007: the physical science basis. Contribution of Working Group I to the Fourth Assessment Report of the Intergovernmental Panel on Climate Change. Cambridge University Press, Cambridge, UK.

Bingeman K, Berhes F, James S, Gardner JS. 2004. Institutional responses to development pressures: Resilience of social-ecological systems in Himachal Pradesh, India. Int. J. Sustain. Dev. World Ecol. 11: 99-115.

BMZ. 2012. Sustainable watershed management in the Lower Mekong Basin. Bonn, German Federal Ministry for Economic Cooperation and Development http://www.giz.de/themen/en/30310.htm.

Bommarco R, Kleijn D, Potts SG. 2012) Ecological intensification: harnessing ecosystem services for food security. Trends in Ecology and Evolution 1629, p 9.

Bradshaw CJA, Sodhi NS, Peh KSH, Brook BW. 2007. Global evidence that deforestation amplifies flood risk and severity in the developing world. Global Change Biology 13: 2379-2395.

Castella JC, Lestrelin G, Hett C, Bourgoin J, Fitriana YR, Heinimann A, Pfund JL. 2013. Effects of landscape segregation on livelihood vulnerability: moving from extensive shifting cultivation to rotational agriculture and natural forests in Northern Laos. Humid Ecoly 41:63-76. DOI 10.1007/s10745-012-9538-8.

Cook ER, Anchukaitis KJ, Buckley BM, D’Arrigo RD, Jacoby GC, Wright WE. 2010. Asian monsoon failure and mega drought during the last millennium. Science 328: 486-489.

Coupe RH, Barlow JRB, Capel PD. 2012. Complexity of human and ecosystem interactions in an agricultural landscape. Environmental Development 4: 88-104.

Chaplot V, Bouahom B, Valentin C. 2010. Soil organic carbon stocks in Laos: spatial variations and controlling factors. Global Change Biology 16:1380-1393.

Cruz RV, Harasawa H, Lal M, Wu S, Anokhin Y, Punsalmaa B, Honda Y, Jafari M, Li C, Nguyen HN. 2007. Asia. In: Parry ML, Canziani OF, Palutikof JP, van der Linden PJ, Hanson CE (eds) Climate Change 2007: Impacts, adaptation and vulnerability. Contribution of Working Group II to the Fourth Assessment Report of the Intergovernmental Panel on Climate Change. Cambridge University Press, Cambridge, UK.

Dasgupta S, Deichmann U, Meisner C, Wheeler D. 2005. Where is the poverty-environment nexus? Evidence from Cambodia, Laos and Vietnam. World Development 33: 617-638.

Egan JF, Mortensen DA. 2012. A comparison of land-sharing and land-sparing strategies for plant richness conservation in agricultural landscapes. Ecological Application 22: 459-471.

[FAO] Food and Agriculture Organization of the United Nations. 2008. Forest and Water. FAO Forest Paper 155. A study prepared in the framework of the Global Forest Resources Assessment 2005. Food and Agriculture Organization of the United Nations, Rome, Italy.

Foley JA, Fries RD, Asner GP, Barford C, Bonan G, Carpenter SR, Chapin FS, Coe MT, Daily GC, Gibbs HK, Helkowski JH, Holloway T, Howard EA, Kucharik C, Monfreda C, Patz JA, Prentice IC, Ramankutty N, Snyder PK. 2005. Global consequences of land use. Science 309: 570-574. 
Folke C. 2006. Resilience: the emergence of a perspective for social-ecological systems analyses. Global Environmental Change - Human and Policy Dimensions 16(3): 253-267.

Folke C, Carpenter RS, Walker B. Scheffer M, Chapin T, Rockström J. 2010. Resilience thinking: integrating resilience, adaptability and transformability. Ecology and Society 15(4): 20. [online] URL: http://www.ecologyandsociety.org/vol15/iss4/art20/

Fox J, Vogler J. 2005. Land-use and land-cover change in montane mainland Southeast Asia. Environmental Management 36(3): 394-403.

Garrity D. 2012. Agroforestry and the future of global land use. In: Ramachandran Nair, PK, Garrity D (eds) Agroforestry: The future of global land use. Advances in Agroforestry series, Springer, Heidelberg. 92012: 21-27.

Go'mez-Baggethun E, Ruiz-Pe'rez M. 2011. Economic valuation and the commodification of ecosystem services. Progress in Physical Geography 35(5): 613-628.

Godfray HCJ, Beddington JR, Crute $I R$, Haddad $L$, Lawrence $D$, Muir JF, Pretty J, Robinson S, Thomas SM, Toulmin C. 2010. Food security: the challenge of feeding 9 billion people. Science 327:812-817.

Grandstaff SW, Terry W, Grandstaff B, Rathakette P, Thomas DE, Thomas JK (1986) Trees in paddy fields in Northeast Thailand. In: Marten GG (editor), Traditional agriculture in Southeast Asia: a human ecology perspective. Westview Press Boulder, Colorado: 273-292.

Grumbine RE, Xu J. 2011. Mekong hydropower development. Science 332: 178-179.

Harvey CA, Chacon M, Donatti CI, Garen E, Hannah L, Andrade A, Bede L, Brown D, Calle A, Chara J, Clement C, Gray E, Hoang MH, Minang P, AnaMar'1a Rodriguez AM, SeebergElverfeldt C, Semroc B, Shames S, Smukler S, Somarriba E, Torquebiau E, Van Etten J Wollenberg E (2013) Climate-smart landscapes: opportunities and challenges for integrating adaptation and mitigation in tropical agriculture. Conservation Letters 00: 1-14.

Hall D, Hirsch P, Li MT. 2011. Powers of exclusion: land dilemmas in Southeast Asia. Singapore and Honolulu: National University of Singapore Press, Singapore and University of Hawaii Press, Honolulu.

Hoang MH, Namirembe S, Van Noordwijk M, Catacutan D, Öborn I, Pérez-Terán A, Nguyen HQ, Dumas-Johansen M. 2013a. Farmer portfolios, strategic diversity management and climate change adaptation - Implications for policy in Vietnam and Kenya. Climate and Development (in press). DOI 10.1080/17565529.2013.857588.

Hoang MH, Do TH, Pham MT, van Noordwijk M, Minang PA. 2013b. Benefit distribution across scales to reduce emissions from deforestation and forest degradation (REDD+) in Vietnam. Land Use Policy 31: 48-60.

Hoang MH, Do TH, van Noordwijk M, Pham TT, Palm M, To XP, Doan D, Nguyen TX, Hoang TVA. 2011. An assessment of opportunities for reducing emission from all land uses: Vietnam preparing for REDD. Final National Report. World Agroforestry Centre (ICRAF), Nairobi, Kenya.

Hoang Fagerström MH, Nilsson SI, van Noordwijk M, Thai P, Olsson M, Hansson A, Svensson C. 2002. Does Tephrosia Candida as fallow species, hedgerow or mulch improve nutrient cycling and prevent nutrient losses by erosion on slopes in Northern Vietnam? Agriculture, Ecosystems and Environment 90: 291-304.

Hoang Fagerström MH, van Noordwijk M, Thai P, Nguyen CV. 2001. Innovations within upland ricebased systems in Northern Vietnam with Tephrosia Candida as fallow species, hedgerow, or mulch: net returns and farmers' response. Agriculture, Ecosystems and Environment 86: 23-37. 
Idol T, Haggar J, Cox L. 2011. Ecosystem services from smallholder forestry and agroforestry in the tropics. In: Campbell WB, Lopez Ortiz S (eds) Integrating agriculture, conservation and ecotourism: examples from the field. Issues in agroecology: present status and future prospectus, vol 1. Springer Netherlands:209-270.

Ilstedt U, Malmer A, Verbeeten E, Murdiyarso D. 2009. The effect of afforestation on water infiltration in the tropics: A systematic review and meta-analysis. Forest Ecology and Management 251:45-51.

Jacobs JW. 1994. Toward sustainability in Lower Mekong River Basin development. Water International 191): 43-51.

Jorgensen SE. 1997. Integration of ecosystem theories: a pattern, 2nd edition. Kluwer, Dordrecht, 388pp.

Kosaka Y, Takeda S, Prixar S, Sithirajvongsa S, Xaydala K. 2006. Species composition, distribution and management of trees in rice paddy fields in Central Lao, PDR. Agroforestry Systems 67: $1-17$.

Kumaraswamy S. 2012. Sustainability issues in agro-ecology: Socio-ecological perspective. Agricultural Sciences Vol.3, No.2, 153-169. DOI 10.4236/as.2012.32018.

Levin SA. 1998. Ecosystems and the biosphere as complex adaptive systems. Ecosystems 1: 431-436.

Levin SA and Lubchenco J. 2008. Resilience, robustness, and marine ecosystem based management. Bioscience 581): 27-32.

Levin S, Xepapadeas T, Crépin AS, Norberg J, de Zeeuw A, Folke C, Hughes T, Arrow K, Barrett S, Daily G, Ehrlich P, Kautsky N, Mäler KG, Polasky S, Troell M, Jeffrey R, Vincent JR, Walker B. 2013. Social-ecological systems as complex adaptive systems: modeling and policy implications. Environment and Development Economics, 18: 111-132. DOI 10.1017/S1355770X12000460.

Lusiana B, van Noordwijk M, Suyamto D, Joshi L, Cadisch G. 2011. Users' perspectives on validity of a simulation model for natural resource management. International Journal of Agricultural Sustainability 9(2):364-378.

Lusiana B, van Noordwijk M, Cadisch G. 2012. Land sparing or sharing? Exploring livestock fodder options in combination with land use zoning and consequences for livelihoods and net carbon stocks using the FALLOW model. Agriculture, Ecosystems and Environment 159:145-160.

Li Z, Fox J. 2011. Mapping rubber tree growth in mainland Southeast Asia using time-series MODIS $250 \mathrm{~m}$ NDVI and Statistical Data. Applied Geography 32: 420-432.

Ly P, Pillot D, Lamballe P, Neergaard AD. 2012. Evaluation of bamboo as an alternative cropping strategy in the Northern Central Upland of Vietnam: above-ground carbon fixing capacity, accumulation of soil organic carbon, and socio-economic aspects. Agriculture, Ecosystem and Environment 149: 80-90.

Manton MJ, Della-Marta PM, Haylock MR, Hennessy KJ, Nicholls N, Chambers LE, Collins DA, Daw G, Finet A, Gunawan D, Inape K, Isobe H, Kestin TS, Lefale P, Leyu CH, Lwin T, Maitrepierre L, Oprasitwong N, Page CM, Pahalad J, Plummer N, Salinger MJ, Suppiah R, Tran VL, Trewin B, Tibig I, Yee D. 2001. Trends in extreme daily rainfall and temperature in Southeast Asia and the South Pacific: 1961-1998. International Journal of Climatology 21: 269-284.

Matocha J, Shroth G, Hills T, Hole D. 2012. Integrating climate change adaptation and mitigation through agroforestry and ecosystem conservation. In: Nair PKR, Garrity D, (eds). Agroforestry: The Future of Global Land Use. Advances in Agroforestry series, Springer, Heidelberg 9: 105126. 
Mainuddin M, Kirby M, Hoanh CT. 2012. Water productivity responses and adaptation to climate change in the Lower Mekong Basin. Water International 371): 53-74.

Mainuddin M, Kirby M. 2009. Agricultural productivity in the lower Mekong Basin: trends and future prospects for food security. Food Sec.1:71-82. DOI 10.1007/s12571-008-0004-9.

Malmer A, Murdiyarso D, Bruijnzeel LA, Ilstedt U. 2010. Carbon sequestration in tropical forest and water: a critical look at the basis for commonly used generalizations. Global Change Biology 16: 599-604.

Meyfroidt P, Lambin EF. 2009. Forest transition in Vietnam and displacement of deforestation abroad. Proceedings of the National Academy of Sciences 106(38): 16139-16144.

MRC. 2004. Annual report 2004. Mekong River Commission, Vientiane, Lao PDR.

Namirembe S, Leimona B, van Noordwijk M, Bernard F, Bacway KE. 2013. Co-investment paradigms as alternatives to payments for tree-based ecosystem services in Africa. Current Opinion in Environmental Sustainability. www.sciencedirect.com.

NIC. 2010. Southeast Asia: The impact of climate change to 2030: geopolitical implications. CR2010-02. National Intelligence Council, Washington, DC, USA.

Nguyen Q, Hoang MH, Öborn I, van Noordwijk M. 2012. Multipurpose agroforestry as a climate change adaptation option for farmers: an example of local adaptation in Vietnam. Climatic Change 117: 241-257.

Nyhus P, Tilson R. 2004. Agroforestry, elephants, and tigers: balancing conservation theory and practice in human-dominated landscapes of Southeast Asia. Agriculture, Ecosystems and Environment 104: 87-97.

Overpeck JT, Cole JE. 2007. Lessons From a distant monsoon. Nature 445: 270-271.

Ordonez J, Luedeling E, Kindt R, Tata HL, Harja D, Jamnadass R and van Noordwijk M (2013) Constraints and opportunities for tree diversity management along the forest transition curve to achieve multifunctional agriculture. Current Opinion in Environmental Sustainability. http://www.sciencedirect.com/science/article/pii/S1877343513001395

PADP. 2003. Review of protected areas and development in the four countries of the Lower Mekong River Region. Vol. 1. International Centre for Environmental Management, Melbourne, Australia.

Pech S and Sunada K. 2008. Population growth and natural-resources pressures in the Mekong River Basin. Ambio 37(3). Available from http://www.ambio.kva.se.

Pramova E, Locatelli B, Djoudi H, Somorin OA. 2012. Forests and trees for social adaptation to climate variabilityand change. WIREs Climate Change 3:581-596. DOI 10.1002/wcc.195.

Rowcroft P. 2008. Frontiers of change: the reasons behind land-use change in the Mekong Basin. Ambio 37(3): 213-218.

Rutger de Wit R, Stal LJ, Lomstein BA, Herbert RA, van Gemerden H, Viaroli P, Cecherelli VU, Rodriguez-Valera F, Bartoli M, Giordani G, Azzoni R, Schaub B, Welsh DT, Donnelly A, Cifuentes A, Anton J, Finster K, Nielsen LB, Pedersen AGU, Neubauer AT, Marina A, Colangelo MA, Sander K, Heij SK. 2001. ROBUST: The role of buffering capacities in stabilising coastal lagoon ecosystems. Continental Shelf Research 21: 2021-2041.

Scherr SJ, Shames S, Friedman R. 2012. From climate-smart agriculture to climate-smart landscapes. Agriculture and Food Security 2012, 1:12.

Sekhar NU. 2007. Traditional Versus Improved Agroforestry Systems in Vietnam: A Comparison. Land Degradation and Development 18: 89-97. 
Simien A, Penot E. 2011. Current evolution of smallholder rubber-based farming systems in Southern Thailand. Journal of Sustainable Forestry 30(3): 247-260.

Sunderlin WD, Resosudarmo IAP. 1996. Rates and causes of deforestation in Indonesia: toward a resolution of ambiguities. Center for International Forestry Research, Bogor, Indonesia .

Steffen W, Sanderson A, Tyson PD, Jager J, Matson PA, Moore B, Oldfield F, Richardson K, Schellnhuber HJ, Turner BL, Wasson RJ. 2004. Global change and the Earth system: a planet under pressure. Heidelberg: Springer, Heidelberg.

Sneddon C, Fox C. 2007. Power, development, and institutional change: participatory governance in the Lower Mekong Basin. World Development 35(12): 2161-2181.

Spelanza CI. 2013. Buffer capacity: capturing a dimension of resilience to climate change in African smallholder agriculture. Regional Environmental Change 13:521-535. DOI 10.1007/s10113012-0391-5.

Tengo M, Belfrage K. 2004. Local management practices for dealing with change and uncertainty: a cross-scale comparison of cases in Sweden and Tanzania. Ecology and Society 9(3): 4.

Ummenhofer CC, Gupta AS, Li Y, Taschetto AS, England MH. 2011. Multi-decadal modulation of the El Niño-Indian Monsoon relationship by Indian Ocean variability. Environmental Research Letters 6.

UNEP. 2012. The benefits of soil carbon: managing soils for multiple economic, societal and environmental benefits. UNEP year book 2012, United Nations Environment Programme, Nairobi, Kenya.

van Noordwijk M, Tata HL, Xu J, Dewi S, Minang PA. 2012. Segregate or integrate for multifunctionality and sustained change through rubber-based agroforestry in Indonesia and China. In: Nair PKR, Garrity D (eds) Agroforestry: The Future of Global Land Use. Advances in Agroforestry seriers, Springer, Heidelberg 9: 69-104.

van Noordwijk M, Hoang MH, Neufeldt H, Öborn I, Yatich T (eds). 2011a. How trees and people can co-adapt to climate change: reducing vulnerability through multifunctional agroforestry landscapes. Nairobi: World Agroforestry Centre (ICRAF), Nairobi, Kenya.

van Noordwijk M, Lusiana B, Khasanah N, Mulia R. 2011b. WaNuLCAS version 4.0. Background on a model of water nutrient and light capture in agroforestry systems. World Agroforestry Centre (ICRAF) Southeast Asia Program. Bogor, Indonesia.

Verburg PH, van de Steeg J, Veldkamp A, Willemen L. 2009. From land cover change to land function dynamics: A major challenge to improve land characterization. Journal of Environmental Management 90:1327-1335.

Viglizzo EF, Paruelo JM, Laterra P, Jobbagy EG. 2012. Ecosystem service evaluation to support landuse policy. Agriculture, Ecosystems and Environment 154: 78-84.

Willemen L, Hart A, Negra C, Harvey C, Laestadius L, Louman B, Place F, Winterbottom R, Scherr, S. 2013. Taking tree-based ecosystem approaches to scale: evidence of drivers and impacts on food security, climate change resilience and carbon sequestration. Ecoagriculture Discussion Paper No.11.EcoAgriculture Partners, Washington, DC.

Villamor GB, van Noordwijk M. 2011. Social role play games versus individual perceptions of conservation and PES agreements for maintaining rubber agroforests in Jambi (Sumatra), Indonesia. Ecology and Society. Available from http://www.ecologyandsociety.org/vol16/iss3/art27.

Villamor GB. 2012. Flexibility of multi-agent system models for rubber agroforest landscapes and social response to emerging reward mechanisms for ecosystem services in Sumatra, Indonesia. University of Bonn Press, Bonn, Germany. 
Wertz-Kanounnikoff S, Locatelli B, Wunder S, Brockhaus M. 2011. Ecosystem-based adaptation to climate change: what scope for payments for environmental services? Climate and Development 3:143-158.

Zheng HT, Zhang YP, Song QH, Liu WJ, Deng XB, Tang JW, Deng Y, Zhou WJ, Yang LY, Yu JR, Sun XM, Liang NS. 2011. Rubber plantations act as water pumps in tropical China. Geophysical Research Letters 38, L24406. 


\section{WORKING PAPERS IN THIS SERIES}

\section{5}

1. Agroforestry in the drylands of eastern Africa: a call to action

2. Biodiversity conservation through agroforestry: managing tree species diversity within a network of community-based, nongovernmental, governmental and research organizations in western Kenya.

3. Invasion of prosopis juliflora and local livelihoods: Case study from the Lake Baringo area of Kenya

4. Leadership for change in farmers organizations: Training report: Ridar Hotel, Kampala, 29th March to 2nd April 2005.

5. Domestication des espèces agroforestières au Sahel : situation actuelle et perspectives

6. Relevé des données de biodiversité ligneuse: Manuel du projet biodiversité des parcs agroforestiers au Sahel

7. Improved land management in the Lake Victoria Basin: TransVic Project's draft report.

8. Livelihood capital, strategies and outcomes in the Taita hills of Kenya

9. Les espèces ligneuses et leurs usages: Les préférences des paysans dans le Cercle de Ségou, au Mali

10. La biodiversité des espèces ligneuses: Diversité arborée et unités de gestion du terroir dans le Cercle de Ségou, au Mali

11. Bird diversity and land use on the slopes of Mt. Kilimanjaro and the adjacent plains, Tanzania

12. Water, women and local social organization in the Western Kenya Highlands

13. Highlights of ongoing research of the World Agroforestry Centre in Indonesia

14. Prospects of adoption of tree-based systems in a rural landscape and its likely impacts on carbon stocks and farmers' welfare: The FALLOW Model Application in Muara Sungkai, Lampung, Sumatra, in a 'Clean Development Mechanism' context

15. Equipping integrated natural resource managers for healthy Agroforestry landscapes.

17. Agro-biodiversity and CGIAR tree and forest science: approaches and examples from Sumatra.

18. Improving land management in eastern and southern Africa: A review of policies.

19. Farm and household economic study of Kecamatan Nanggung, Kabupaten Bogor, Indonesia: A socio-economic base line study of Agroforestry innovations and livelihood enhancement.

20. Lessons from eastern Africa's unsustainable charcoal business.

21. Evolution of RELMA's approaches to land management: Lessons from two decades of research and development in eastern and southern Africa

22. Participatory watershed management: Lessons from RELMA's work with farmers in eastern Africa.

23. Strengthening farmers' organizations: The experience of RELMA and ULAMP.

24. Promoting rainwater harvesting in eastern and southern Africa.

25. The role of livestock in integrated land management.

26. Status of carbon sequestration projects in Africa: Potential benefits and challenges to scaling up.

27. Social and Environmental Trade-Offs in Tree Species Selection: A Methodology for Identifying Niche Incompatibilities in Agroforestry [Appears as AHI Working Paper no. 9]

28. Managing tradeoffs in agroforestry: From conflict to collaboration in natural resource management. [Appears as AHI Working Paper no. 10] 
29. Essai d'analyse de la prise en compte des systemes agroforestiers pa les legislations forestieres au Sahel: Cas du Burkina Faso, du Mali, du Niger et du Senegal.

30. Etat de la recherche agroforestière au Rwanda etude bibliographique, période 1987-2003

2007

31. Science and technological innovations for improving soil fertility and management in Africa: A report for NEPAD's Science and Technology Forum.

32. Compensation and rewards for environmental services.

33. Latin American regional workshop report compensation.

34. Asia regional workshop on compensation ecosystem services.

35. Report of African regional workshop on compensation ecosystem services.

36. Exploring the inter-linkages among and between compensation and rewards for ecosystem services CRES and human well-being

37. Criteria and indicators for environmental service compensation and reward mechanisms: realistic, voluntary, conditional and pro-poor

38. The conditions for effective mechanisms of compensation and rewards for environmental services.

39. Organization and governance for fostering Pro-Poor Compensation for Environmental Services.

40. How important are different types of compensation and reward mechanisms shaping poverty and ecosystem services across Africa, Asia \& Latin America over the Next two decades?

41. Risk mitigation in contract farming: The case of poultry, cotton, woodfuel and cereals in East Africa.

42. The RELMA savings and credit experiences: Sowing the seed of sustainability

43. Yatich J., Policy and institutional context for NRM in Kenya: Challenges and opportunities for Landcare.

44. Nina-Nina Adoung Nasional di So! Field test of rapid land tenure assessment (RATA) in the Batang Toru Watershed, North Sumatera.

45. Is Hutan Tanaman Rakyat a new paradigm in community based tree planting in Indonesia?

46. Socio-Economic aspects of brackish water aquaculture (Tambak) production in Nanggroe Aceh Darrusalam.

47. Farmer livelihoods in the humid forest and moist savannah zones of Cameroon.

48. Domestication, genre et vulnérabilité : Participation des femmes, des Jeunes et des catégories les plus pauvres à la domestication des arbres agroforestiers au Cameroun.

49. Land tenure and management in the districts around Mt Elgon: An assessment presented to the Mt Elgon ecosystem conservation programme.

50. The production and marketing of leaf meal from fodder shrubs in Tanga, Tanzania: A pro-poor enterprise for improving livestock productivity.

51. Buyers Perspective on Environmental Services (ES) and Commoditization as an approach to liberate ES markets in the Philippines.

52. Towards Towards community-driven conservation in southwest China: Reconciling state and local perceptions.

53. Biofuels in China: An Analysis of the Opportunities and Challenges of Jatropha curcas in Southwest China.

54. Jatropha curcas biodiesel production in Kenya: Economics and potential value chain development for smallholder farmers

55. Livelihoods and Forest Resources in Aceh and Nias for a Sustainable Forest Resource Management and Economic Progress 
56. Agroforestry on the interface of Orangutan Conservation and Sustainable Livelihoods in Batang Toru, North Sumatra.

57. Assessing Hydrological Situation of Kapuas Hulu Basin, Kapuas Hulu Regency, West Kalimantan.

58. Assessing the Hydrological Situation of Talau Watershed, Belu Regency, East Nusa Tenggara.

59. Kajian Kondisi Hidrologis DAS Talau, Kabupaten Belu, Nusa Tenggara Timur.

60. Kajian Kondisi Hidrologis DAS Kapuas Hulu, Kabupaten Kapuas Hulu, Kalimantan Barat.

61. Lessons learned from community capacity building activities to support agroforest as sustainable economic alternatives in Batang Toru orang utan habitat conservation program (Martini, Endri et al.)

62. Mainstreaming Climate Change in the Philippines.

63. A Conjoint Analysis of Farmer Preferences for Community Forestry Contracts in the Sumber Jaya Watershed, Indonesia.

64. The highlands: a shared water tower in a changing climate and changing Asia

65. Eco-Certification: Can It Deliver Conservation and Development in the Tropics.

66. Designing ecological and biodiversity sampling strategies. Towards mainstreaming climate change in grassland management.

67. Towards mainstreaming climate change in grassland management policies and practices on the Tibetan Plateau

68. An Assessment of the Potential for Carbon Finance in Rangelands

69 ECA Trade-offs Among Ecosystem Services in the Lake Victoria Basin.

69. The last remnants of mega biodiversity in West Java and Banten: an in-depth exploration of RaTA (Rapid Land Tenure Assessment) in Mount Halimun-Salak National Park Indonesia

70. Le business plan d'une petite entreprise rurale de production et de commercialisation des plants des arbres locaux. Cas de quatre pépinières rurales au Cameroun.

71. Les unités de transformation des produits forestiers non ligneux alimentaires au Cameroun. Diagnostic technique et stratégie de développement Honoré Tabuna et Ingratia Kayitavu.

72. Les exportateurs camerounais de safou (Dacryodes edulis) sur le marché sous régional et international. Profil, fonctionnement et stratégies de développement.

73. Impact of the Southeast Asian Network for Agroforestry Education (SEANAFE) on agroforestry education capacity.

74. Setting landscape conservation targets and promoting them through compatible land use in the Philippines.

75. Review of methods for researching multistrata systems.

76. Study on economical viability of Jatropha curcas L. plantations in Northern Tanzania assessing farmers' prospects via cost-benefit analysis

77. Cooperation in Agroforestry between Ministry of Forestry of Indonesia and International Center for Research in Agroforestry

78. "China's bioenergy future. an analysis through the Lens if Yunnan Province

79. Land tenure and agricultural productivity in Africa: A comparative analysis of the economics literature and recent policy strategies and reforms

80. Boundary organizations, objects and agents: linking knowledge with action in agroforestry watersheds

81. Reducing emissions from deforestation and forest degradation (REDD) in Indonesia: options and challenges for fair and efficient payment distribution mechanisms

82. Mainstreaming climate change into agricultural education: challenges and perspectives 
83. Challenging conventional mindsets and disconnects in conservation: the emerging role of ecoagriculture in Kenya's landscape mosaics

84. Lesson learned RATA garut dan bengkunat: suatu upaya membedah kebijakan pelepasan kawasan hutan dan redistribusi tanah bekas kawasan hutan

85. The emergence of forest land redistribution in Indonesia

86. Commercial opportunities for fruit in Malawi

87. Status of fruit production processing and marketing in Malawi

88. Fraud in tree science

89. Trees on farm: analysis of global extent and geographical patterns of agroforestry

90. The springs of Nyando: water, social organization and livelihoods in Western Kenya

91. Building capacity toward region-wide curriculum and teaching materials development in agroforestry education in Southeast Asia

92. Overview of biomass energy technology in rural Yunnan (Chinese - English abstract)

93. A pro-growth pathway for reducing net GHG emissions in China

94. Analysis of local livelihoods from past to present in the central Kalimantan Ex-Mega Rice Project area

95. Constraints and options to enhancing production of high quality feeds in dairy production in Kenya, Uganda and Rwanda

\section{0}

96. Agroforestry education in the Philippines: status report from the Southeast Asian Network for Agroforestry Education (SEANAFE)

97. Economic viability of Jatropha curcas L. plantations in Northern Tanzania- assessing farmers' prospects via cost-benefit analysis.

98. Hot spot of emission and confusion: land tenure insecurity, contested policies and competing claims in the central Kalimantan Ex-Mega Rice Project area

99. Agroforestry competences and human resources needs in the Philippines

100. CES/COS/CIS paradigms for compensation and rewards to enhance environmental Services

101. Case study approach to region-wide curriculum and teaching materials development in agroforestry education in Southeast Asia

102. Stewardship agreement to reduce emissions from deforestation and degradation (REDD): Lubuk Beringin's Hutan Desa as the first village forest in Indonesia

103. Landscape dynamics over time and space from ecological perspective

104. Komoditisasi atau koinvestasi jasa lingkungan: skema imbal jasa lingkungan program peduli sungai di DAS Way Besai, Lampung, Indonesia

105. Improving smallholders' rubber quality in Lubuk Beringin, Bungo district, Jambi province, Indonesia: an initial analysis of the financial and social benefits

106. Rapid Carbon Stock Appraisal (RACSA) in Kalahan, Nueva Vizcaya, Philippines

107. Tree domestication by ICRAF and partners in the Peruvian Amazon: lessons learned and future prospects in the domain of the Amazon Initiative eco-regional program

108. Memorias del Taller Nacional: "Iniciativas para Reducir la Deforestación en la region Andino Amazónica", 09 de Abril del 2010. Proyecto REALU Peru

109. Percepciones sobre la Equidad y Eficiencia en la cadena de valor de REDD en Perú - Reporte de Talleres en Ucayali, San Martín y Loreto, 2009. Proyecto REALU-Perú.

110. Reducción de emisiones de todos los Usos del Suelo. Reporte del Proyecto REALU Perú Fase 1

111. Programa Alternativas a la Tumba-y-Quema (ASB) en el Perú. Informe Resumen y Síntesis de la Fase II. 2da. versión revisada

112. Estudio de las cadenas de abastecimiento de germoplasma forestal en la amazonía Boliviana 
113. Biodiesel in the Amazon

114. Estudio de mercado de semillas forestales en la amazonía Colombiana

115. Estudio de las cadenas de abastecimiento de germoplasma forestal en Ecuador http://dx.doi.org10.5716/WP10340.PDF

116. How can systems thinking, social capital and social network analysis help programs achieve impact at scale?

117. Energy policies, forests and local communities in the Ucayali Region, Peruvian Amazon

118. NTFPs as a Source of Livelihood Diversification for Local Communities in the Batang Toru Orangutan Conservation Program

119. Studi Biodiversitas: Apakah agroforestry mampu mengkonservasi keanekaragaman hayati di DAS Konto?

120. Estimasi Karbon Tersimpan di Lahan-lahan Pertanian di DAS Konto, Jawa Timur

121. Implementasi Kaji Cepat Hidrologi (RHA) di Hulu DAS Brantas, Jawa Timur. http://dx.doi.org/10.5716/WP10338.PDF

122. Kaji Cepat Hidrologi di Daerah Aliran Sungai Krueng Peusangan, NAD,Sumatra http://dx.doi.org/10.5716/WP10337.PDF

123. A Study of Rapid Hydrological Appraisal in the Krueng Peusangan Watershed, NAD, Sumatra. http://dx.doi.org/10.5716/WP10339.PDF

\section{1}

124. An Assessment of farm timber value chains in Mt Kenya area, Kenya

125. A Comparative financial analysis of current land use systems and implications for the adoption of improved agroforestry in the East Usambaras, Tanzania

126. Agricultural monitoring and evaluation systems

127. Challenges and opportunities for collaborative landscape governance in the East Usambara Mountains, Tanzania

128. Transforming Knowledge to Enhance Integrated Natural Resource Management Research, Development and Advocacy in the Highlands of Eastern Africa. http://dx.doi.org/10.5716/WP11084.PDF

129. Carbon-forestry projects in the Philippines: potential and challenges The Mt Kitanglad Range forest-carbon development. http://dx.doi.org10.5716/WP11054.PDF

130. Carbon forestry projects in the Philippines: potential and challenges. The Arakan Forest Corridor forest-carbon project. http://dx.doi.org10.5716/WP11055.PDF

131. Carbon-forestry projects in the Philippines: potential and challenges. The Laguna Lake Development Authority's forest-carbon development project. http://dx.doi.org/10.5716/WP11056.PDF

132. Carbon-forestry projects in the Philippines: potential and challenges. The Quirino forest-carbon development project in Sierra Madre Biodiversity Corridor. http://dx.doi.org10.5716/WP11057.PDF

133. Carbon-forestry projects in the Philippines: potential and challenges. The Ikalahan Ancestral Domain forest-carbon development. http://dx.doi.org10.5716/WP11058.PDF

134. The Importance of Local Traditional Institutions in the Management of Natural Resources in the Highlands of Eastern Africa. http://dx.doi.org/10.5716/WP11085.PDF

135. Socio-economic assessment of irrigation pilot projects in Rwanda. http://dx.doi.org/10.5716/WP11086.PDF

136. Performance of three rambutan varieties(Nephelium lappaceum L.) on various nursery media. http://dx.doi.org/10.5716/WP11232.PDF 
137. Climate change adaptation and social protection in agroforestry systems: enhancing adaptive capacity and minimizing risk of drought in Zambia and Honduras.

http://dx.doi.org/10.5716/WP11269.PDF

138. Does value chain development contribute to rural poverty reduction? Evidence of asset building by smallholder coffee producers in Nicaragua. http://dx.doi.org/10.5716/WP11271.PDF

139. Potential for biofuel feedstock in Kenya. http://dx.doi.org/10.5716/WP11272.PDF

140. Impact of fertilizer trees on maize production and food security in six districts of Malawi. http://dx.doi.org/10.5716/WP11281.PDF

\section{2}

141. Fortalecimiento de capacidades para la gestión del Santuario Nacional Pampa Hermosa:

Construyendo las bases para un manejo adaptativo para el desarrollo local. Memorias del Proyecto. http://dx.doi.org/10.5716/WP12005.PDF

142. Understanding rural institutional strengthening: A cross-level policy and institutional framework for sustainable development in Kenya. http://dx.doi.org/10.5716/WP12012.PDF

143. Climate change vulnerability of agroforestry. http://dx.doi.org/10.5716/WP16722.PDF

144. Rapid assesment of the inner Niger delta of Mali. http://dx.doi.org/10.5716/WP12021.PDF

145. Designing an incentive program to reduce on-farm deforestationin the East Usambara Mountains, Tanzania. http://dx.doi.org/10.5716/WP12048.PDF

146. Extent of adoption of conservation agriculture and agroforestry in Africa: the case of Tanzania, Kenya, Ghana, and Zambia. http://dx.doi.org/10.5716/WP12049.PDF

147. Policy incentives for scaling up conservation agriculture with trees in Africa: the case of Tanzania, Kenya, Ghana and Zambia. http://dx.doi.org/10.5716/WP12050.PDF

148. Commoditized or co-invested environmental services? Rewards for environmental services scheme: River Care program Way Besai watershed, Lampung, Indonesia. http://dx.doi.org/10.5716/WP12051.PDF

149. Assessment of the headwaters of the Blue Nile in Ethiopia. http://dx.doi.org/10.5716/WP12160.PDF

150. Assessment of the uThukela Watershed, Kwazaulu. http://dx.doi.org/10.5716/WP12161.PDF

151. Assessment of the Oum Zessar Watershed of Tunisia. http://dx.doi.org/10.5716/WP12162.PDF

152. Assessment of the Ruwenzori Mountains in Uganda. http://dx.doi.org/10.5716/WP12163.PDF

153. History of agroforestry research and development in Viet Nam. Analysis of research opportunities and gaps. http://dx.doi.org/10.5716/WP12052.PDF

154. REDD+ in Indonesia: a Historical Perspective. http://dx.doi.org/10.5716/WP12053.PDF

155. Agroforestry and Forestry in Sulawesi series: Livelihood strategies and land use system dynamics in South Sulawesi http://dx.doi.org/10.5716/WP12054.PDF

156. Agroforestry and Forestry in Sulawesi series: Livelihood strategies and land use system dynamics in Southeast Sulawesi. http://dx.doi.org/10.5716/WP12055.PDF

157. Agroforestry and Forestry in Sulawesi series: Profitability and land-use systems in South and Southeast Sulawesi. http://dx.doi.org/10.5716/WP12056.PDF

158. Agroforestry and Forestry in Sulawesi series: Gender, livelihoods and land in South and Southeast Sulawesi http://dx.doi.org/10.5716/WP12057.PDF

159. Agroforestry and Forestry in Sulawesi series: Agroforestry extension needs at the community level in AgFor project sites in South and Southeast Sulawesi, Indonesia. http://dx.doi.org/10.5716/WP12058.PDF

160. Agroforestry and Forestry in Sulawesi series: Rapid market appraisal of agricultural, plantation and forestry commodities in South and Southeast Sulawesi. http://dx.doi.org/10.5716/WP12059.PDF 


\section{3}

161. Diagnosis of farming systems in the Agroforestry for Livelihoods of Smallholder farmers in Northwestern Viet Nam project. http://dx.doi.org/10.5716/WP13033.PDF

162. Ecosystem vulnerability to climate change: a literature review. http://dx.doi.org/10.5716/WP13034.PDF

163. Local capacity for implementing payments for environmental services schemes: lessons from the RUPES project in northeastern Viet Nam. http://dx.doi.org/10.5716/WP13046.PDF

164. Seri Agroforestri dan Kehutanan di Sulawesi: Agroforestry dan Kehutanan di Sulawesi: Strategi mata pencaharian dan dinamika sistem penggunaan lahan di Sulawesi Selatan. http://dx.doi.org/10.5716/WP13040.PDF

165. Seri Agroforestri dan Kehutanan di Sulawesi: Mata pencaharian dan dinamika sistem penggunaan lahan di Sulawesi Tenggara http://dx.doi.org/10.5716/WP13041.PDF

166. Seri Agroforestri dan Kehutanan di Sulawesi: Profitabilitas sistem penggunaan lahan di Sulawesi Selatan dan Sulawesi Tenggara http://dx.doi.org/10.5716/WP13042.PDF

167. Seri Agroforestri dan Kehutanan di Sulawesi: Gender, mata pencarian dan lahan di Sulawesi Selatan dan Sulawesi Tenggara http://dx.doi.org/10.5716/WP13043.PDF

168. Seri Agroforestri dan Kehutanan di Sulawesi: Kebutuhan penyuluhan agroforestri pada tingkat masyarakat di lokasi proyek AgFor di Sulawesi Selatan dan Tenggara, Indonesia. http://dx.doi.org/10.5716/WP13044.PDF

169. Seri Agroforestri dan Kehutanan di Sulawesi: Laporan hasil penilaian cepat untuk komoditas pertanian, perkebunan dan kehutanan di Sulawesi Selatan dan Tenggara. http://dx.doi.org/10.5716/WP13045.PDF

170. Agroforestry, food and nutritional security. http://dx.doi.org/10.5716/WP13054.PDF

171. Stakeholder Preferences over Rewards for Ecosystem Services: Implications for a REDD+ Benefit Distribution System in Viet Nam. http://dx.doi.org/10.5716/WP13057.PDF

172. Payments for ecosystem services schemes: project-level insights on benefits for ecosystems and the rural poor. http://dx.doi.org/10.5716/WP13001.PDF

173. Good practices for smallholder teak plantations keys to success. http://dx.doi.org/10.5716/WP13246.PDF

174. Market analysis of selected agroforestry products in the Vision for Change Project intervention Zone, Côte d'Ivoire.

175. Rattan futures in Katingan: why do smallholders abandon or keep their gardens in Indonesia's 'rattan district'? http://dx.doi.org/10.5716/WP13251.PDF

176. Management along a Gradient: Southeast Sulawesi's Cacao Production Landscape http://dx.doi.org/10.5716/WP13246.PDF

\section{4}

177. Are trees buffering ecosystems and livelihoods in agricultural landscapes of the Lower Mekong Basin? Consequences for climate-change adaptation.

http://dx.doi.org/10.5716/WP14047.PDF 


The World Agroforestry Centre is an autonomous, non-profit research organization whose vision is a rural transformation in the developing world as smallholder households increase their use of trees in agricultural landscapes to improve food security, nutrition, income, health, shelter, social cohesion, energy resources and environmental sustainability. The Centre generates science-based knowledge about the diverse roles that trees play in agricultural landscapes, and uses its research to advance policies and practices, and their implementation that benefit the poor and the environment. It aims to ensure that all this is achieved by enhancing the quality of its science work, increasing operational efficiency, building and maintaining strong partnerships, accelerating the use and impact of its research, and promoting greater cohesion, interdependence and alignment within the organization.

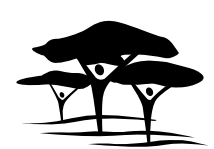

United Nations Avenue, Gigiri • PO Box 30677 • Nairobi, $00100 \cdot$ Kenya Telephone: +254207224000 or via USA +1 6508336645

Fax: +254207224001 or via USA +1 6508336646

Email: worldagroforestry@cgiar.org •www.worldagroforestry.org

Southeast Asia Regional Program • Sindang Barang • Bogor 16680

PO Box $161 \cdot$ Bogor $16001 \cdot$ Indonesia

Telephone: +62 $2518625415 \cdot$ Fax: +62 2518625416

Email: icraf-indonesia@cgiar.org•www.worldagroforestry.org/regions/southeast_asia 